\title{
World Inflation and Monetary Accommodation in Eight Countries
}

The "monetarist" view of . . the acceleration of inflation since 1965 [is] that it has been the ultimate consequence of an increase in the rate of world monetary expansion, an increase attributable primarily to the excessively expansionary monetary policy pursued by the United States in recent years.-Harry G. Johnson ${ }^{1}$

I find the alternative explanation ... which regards the basic cause as increased trade-union militancy ... more plausible.-Nicholas Kaldor ${ }^{2}$

There is little doubt, then, that the wage-inflation idea does not apply to the inflationary experiences we have seen in the real world. . . . Only when the macroeconomic implications of the wage-inflation hypothesis are traced through and confronted with the facts does it become apparent that it cannot be sustained.-Arnold C. Harberger ${ }^{3}$

Note: This research has been supported by the National Science Foundation. I am grateful to my colleague John Bilson for aiding me in the acquisition of data from the International Monetary Fund, and to my research assistant James Glassman for an absolutely outstanding job. Also helpful were the suggestions of Victor Argy, Jacques Artus, Jacob Frenkel, Hans Genberg, John Helliwell, Paul Krugman, David Laidler, Michael Parkin, Richard Sweeney, George Zis, and members of the Brookings panel. Of special value were a number of discussions with Christopher Sims.

1. Harry G. Johnson, "Inflation: A 'Monetarist' View," in Harry G. Johnson, Further Essays in Monetary Economics (Allen \& Unwin, 1972), p. 335.

2. Nicholas Kaldor, "Inflation and Recession in the World Economy," Economic Journal, vol. 86 (December 1976), p. 710.

3. Arnold C. Harberger, "Inflation," in John Van Doren, ed., Symposium on the Emerging World Economy (Great Ideas Today series) (Encyclopaedia Britannica Educational Corporation, 1976), pp. 94-106. 
WHILE "SUPPLY SHOCKS" in oil and food are widely agreed to have aggravated inflation in many countries in 1973-75, no consensus has yet emerged to explain the acceleration of inflation between the mid-1960s and 1970-72 in the major industrialized nations outside of North America. Instead, two major schools of thought, the "international monetarist" and the "wage push," have developed alternative explanations having radically different policy implications. The first group views inflation within a conventional macroeconomic framework as an "international monetary phenomenon" and identifies its fundamental cause as an excess demand for commodities generated by government actions. Any attempt to bring in other factors, particularly those of the wage-push variety, is dismissed. Adherents of the wage-push or "sociological" school of thought disagree, pointing to the allegedly spontaneous wage explosions that occurred in a number of European countries in 1968 and 1970 as evidence of the special noneconomic character of the recent inflation. Wage claims are viewed as part of a continuing conflict over income shares among competing social groups, and the events of the 1968-70 period reflected labor's "long-smouldering resentment and dissatisfaction."

\section{Aims of the Paper}

The sources of inflation in the main industrialized nations in the period of fixed exchange rates have not yet been adequately established. Both the international-monetarist and wage-push arguments are unsatisfactory and incomplete. The acceleration of wages and prices in 1969-70 in the major nations outside of the United States followed a continuing deceleration of their rates of monetary growth between 1963 and 1969. For the "world"- the United States plus seven other important industrial na-

4. Kaldor, "Inflation and Recession," p. 710. In his more eclectic analysis of wages, George L. Perry considers wage push, closely associated with a dissatisfaction with shares, an important part of the wage explosions of the 1968-70 period, and consequently one of the factors that brought the average rate of wage inflation in the 1970s to a new, higher, plateau. See his "Determinants of Wage Inflation around the World," BPEA, 2:1975, pp. 403-35. Earlier, William D. Nordhaus had rejected a related explanation labeled "frustration theories" in "The Worldwide Wage Explosion," BPEA, 2:1972, pp. 431-64. 
tions 5 - the 1969-70 acceleration of wage rates preceded by almost a year the 1971 explosion of money and international reserves, in apparent conflict with the international-monetarist explanation. Wage-push proponents have not made their case either, because autonomous wage increases do not automatically pass into the price level.

This paper accepts from the outset the proposition that world inflation must in the long run be a world monetary phenomenon. Confirmation of a connection between the rates of growth of world money and prices, as in several recent studies, is viewed as only the first step in the development of a fuller understanding of the inflation process, because the sources of changes in world money are left unexplained. ${ }^{6}$ A correlation between world prices and money does not rule out wage push as a source of world monetary growth. Instead of viewing international monetary and wagepush factors as competitive explanations of inflation, a more comprehensive theoretical framework is presented which incorporates these two ingredients as possible explanations of the behavior of the monetary authorities, together with fiscal deficits, supply shocks, and a countercyclical monetary reaction function.

Since a time-series correlation between inflation and monetary growth is consistent with several sources of monetary growth, a more discriminating empirical methodology is required. An impirical study of the United States and seven other major industrial nations attempts to determine whether the data are consistent with an effect of any or all of the possible sources of monetary accommodation.

Among the major questions to be answered are the following: If U.S. monetary growth is to be blamed for the acceleration of inflation in other countries, by what channels was this impulse transmitted? Did patterns of causation differ among countries? Were some countries better able than others to pursue countercyclical rather than procyclical monetary policies? Did differences across countries in the degree of accommodation to supply shocks in 1974 correspond with the degree of accommodation to wage

5. The "Other Seven" countries are Canada, France, West Germany, Italy, Japan, Sweden, and the United Kingdom.

6. See, for instance, David I. Meiselman, "Worldwide Inflation: A Monetarist View," in Meiselman and Arthur B. Laffer, eds., The Phenomenon of Worldwide Inflation (American Enterprise Institute, 1975), pp. 69-112. See also Hans Genberg and Alexander K. Swoboda, "Causes and Origins of the Current Worldwide Inflation," discussion paper (Geneva: Graduate Institute of International Studies, November 1975; processed). 
push or reserve inflows in the earlier period? Do episodes of wage push identified by others appear to have been genuinely exogenous or were they preceded by episodes of monetary accommodation? Can the breakdown of the Bretton Woods system be treated ultimately as another casualty of the Vietnam War, or did domestic events in other countries play a role?

Answers to these questions are useful not only for an understanding of history, but for future policymaking: Is control of the money supply either necessary or sufficient for a nation to control its inflation rate? Is it likely that monetary authorities will be able in the future to insulate the inflation rate from the tendencies to wage push, or are incomes policies required as a cure?

Finally, the paper raises a methodological question of interest to many economists caught in the middle without any particular allegiance to an international-monetarist or wage-push view of the world: Can econometric techniques uncover systematic tendencies toward procyclical accommodation or countercyclical activism on the part of central banks, or do shifting targets and priorities defy statistical generalizations and call instead for a more descriptive and anecdotal approach to monetary history?

\section{International-Monetarist Approach}

The international-monetarist approach begins from the proposition that under fixed exchange rates the world inflation rate is determined primarily by previous changes in the rate of growth of the world money supply. This follows from two basic propositions which previously had been emphasized by U.S. monetarists addressing issues of a closed economy: the stability of the demand-for-money function, and the lack of any long-run tradeoff between inflation and unemployment. Both of these elements have been tested by international-monetarist economists who have estimated structural equations describing the behavior of the demand-for-money function and the expectational Phillips curve for the "world" (usually the Group of Ten). ${ }^{7}$ Further, reduced-form tests have

7. See M. R. Gray, R. Ward, and G. Zis, "The World Demand for Money Function: Some Preliminary Results," and Nigel Duck and others, "The Determination of the Rate of Change of Wages and Prices in the Fixed Exchange Rate World Economy, 1956-71," both in Michael Parkin and George Zis, eds., Inflation in the World Economy (Manchester University Press and University of Toronto Press, 1976), pp. 151-78 and 113-43, respectively. 
found that changes in the world rate of monetary growth have preceded changes in the world inflation rate. ${ }^{8}$

The behavior of individual countries is characterized not only by stable national demand-for-money functions and vertical long-run Phillips curves, but by two additional features. First, capital is mobile among nations, so that international reserves tend to flow in or out as necessary to set a nation's money supply equal to its demand for money, which depends primarily on its price level, real output, and interest rate. ${ }^{9}$ Second, commodity arbitrage maintains the tradable-goods portion of the domestic price level fairly close to the world price level of tradable goods, while labor mobility communicates changes in prices of tradable goods to the nontradables sector. ${ }^{10}$ Thus any event that raises the foreign price level tends to push up both the domestic price level and the domestic money supply, irrespective of the reaction of the domestic monetary authorities.

The international-monetarist approach traces the acceleration of inflation outside the United States in the late 1960s back to U.S. fiscal deficits incurred to pay for Vietnam expenditures, which induced an acceleration in the growth rate of the U.S. money supply and price level. Inflation then spread from the United States to other countries by four main channels of transmission. ${ }^{11}$ First, the "direct price influence" working through commodity arbitrage raised the prices of tradable goods everywhere. This then pushed up the marginal value product of labor and of other factors of production and hence domestic costs, raising the prices of nontradable

8. See Genberg and Swoboda, "Causes and Origins."

9. See Robert A. Mundell, International Economics (Macmillan, 1968), chap. 18; also Harry G. Johnson, "The Monetary Approach to Balance-of-Payments Theory," in Johnson, Further Essays in Monetary Economics, pp. 229-49.

10. Rudiger Dornbusch, "Devaluation, Money, and Nontraded Goods," American Economic Review, vol. 63 (December 1973), pp. 871-80. The Dornbusch model is extended to the case of imperfectly flexible prices in Robert J. Gordon, "Interrelations Between Domestic and International Theories of Inflation," in Robert Z. Aliber, ed., The Political Economy of Monetary Reform (Macmillan, 1977), pp. 126-54.

11. An excellent general discussion of the channels through which inflation is transmitted can be found in Walter S. Salant, "International Transmission of Inflation," in Lawrence B. Krause and Walter S. Salant, eds., Worldwide Inflation: Theory and Recent Experience (Brookings Institution, 1977), pp. 167-227. See also Alexander K. Swoboda, "Monetary Approaches to Worldwide Inflation," in the same volume, especially pp. 33-44. 
goods. ${ }^{12}$ Second, the trade surpluses of other nations induced by the fact that U.S. income growth was higher than their own, as well as by deteriorating U.S. price competitiveness, boosted foreign levels of production and income through the conventional "Keynesian demand-pressure mechanism." Third, the "Bretton Woods monetization channel" allowed U.S. balance-of-payments deficits to be paid for by the creation of U.S. dollar liabilities which expanded the monetary base of many nations and further fueled their own domestic inflation rates. Fourth, an acceleration of U.S. inflation could have raised domestic expectations of inflation directly, leading to higher wage and price increases. The channels were connected, since the direct effects of higher prices for tradable goods, higher real output, and higher expected prices for nontradable goods, all raised a nation's transaction demand for money and, with freely mobile capital, attracted the international reserves needed to bring the domestic money supply into equality with higher money demand.

In the long run under fixed exchange rates, then, policymakers in small countries should regard inflation as part of the external environment rather than under their own control. Domestic "wage push" by unions cannot contribute to domestic inflation; worker groups that achieve a higher nominal wage when the price level is determined abroad can raise their own incomes only at the expense of unemployment and lower profits, particularly in the tradable-goods sector. Incomes policies designed to control wage push may be able to influence the unemployment rate or the distribution of income, but not the inflation rate.

But the international monetarist's denial of a role for an autonomous wage push in the world inflation process is not totally convincing, because the symmetry between tradable-goods prices and domestic wages is ignored. Both are determinants of domestic prices and the transaction demand for money. An autonomous wage push could raise the demand for money and, with perfect capital mobility, suck in the reserves needed to provide the base for a higher domestic money supply. If commodity arbitrage is perfect, the profits of firms in the tradable-goods sector will be squeezed, but there is some evidence that commodity arbitrage is not

12. This is the primary channel of international transmission in the "Scandinavian" model of inflation. See Gösta Edgren, Karl-Olof Faxén, and Clas-Erik Odhner, "Wages, Growth and the Distribution of Income," Swedish Journal of Economics, vol. 71 (September 1969), pp. 133-60. Also Odd Aukrust, "Inflation in the Open Economy: A Norwegian Model," in Krause and Salant, eds., Worldwide Inflation, pp. 107-53. 
perfect, at least in the short run. ${ }^{13}$ The increase in domestic monetary growth would contribute to an acceleration in world monetary growth and in the world rate of inflation, particularly if an autonomous wage push were to occur in several countries simultaneously.

\section{The Wage-Push, or "Sociological," Explanation}

In its most extreme form, proponents of the wage-push view argue that the inflation rate depends entirely on the aggressiveness of labor unions in pressing wage demands. Peter Wiles has claimed, for instance, that "we have moved from wage claims based on the actual situation in the trade ... to claims picked out of the air. . .."14 The underlying source of wage push is viewed variously as a conflict over the fairness of the income distribution and wage structure; as the result of the rise of the tactics of the New Left and the decline of authority; and as a consequence of a communications revolution that increased awareness of foreign wage claims. The independent influence of money and aggregate demand is often viewed as negligible. ${ }^{15}$

While money is sometimes rejected as a cause of wage behavior, changes in money are viewed as a consequence of wage push in many discussions. Sooner or later the central bank will have to raise the money supply in order to accommodate the higher transaction demand for money created by higher wages. Richard Cooper has made this point succinctly:

The wage level in the modern economy is indeterminant because in the final analysis the monetary authorities must-for political reasons-provide a money supply adequate to ratify any given level of money wages, no matter how it was reached, in order to avoid excessive unemployment. ${ }^{16}$

13. See Irving B. Kravis and Robert E. Lipsey, "Export Prices and the Transmission of Inflation," American Economic Review, vol. 67 (February 1977), pp. 155-63. Also see Rudiger Dornbusch and Paul Krugman, "Flexible Exchange Rates in the Short Run," BPEA, 3:1976, especially pp. 559-68.

14. Peter Wiles, "Cost Inflation and the State of Economic Theory," Economic Journal, vol. 83 (June 1973), p. 378.

15. A clear statement emphasizing the fairness issue is contained in John Hicks, The Crisis in Keynesian Economics (Basic Books, 1974), chap. 3.

16. Richard N. Cooper, statement in "Commentaries" on paper by Thomas D. Willet, "The Eurocurrency Market, Exchange-Rate Systems, and National Financial Policies," in Carl H. Stem, John H. Makin, and Dennis E. Logue, eds., Eurocurrencies and the International Monetary System (American Enterprise Institute, 1976), p. 252. 
Some British commentators admit the monetary connection. ${ }^{17}$ But this acknowledgment is by no means universal. ${ }^{18}$

Several investigators have found that wage equations for major European countries require the use of dummy variables to explain particular episodes of sudden acceleration in the rate of wage change. ${ }^{10}$ While a significant positive coefficient on a dummy variable indicates only that something is happening that cannot be otherwise explained, the timing of the wage accelerations correspond to widely recognized incidents of aggressive labor behavior, particularly the French general strike of May 1968, and the Italian "hot autumn" of 1969.

The wage-push explanation has been universally condemned by proponents of the international-monetarist view, but empirical critiques by international monetarists have involved tests of unnecessarily restrictive versions of the sociological approach. For instance, any influence on wages of excess commodity or labor demand or proxies for inflationary expectations is cited as negative evidence, implicitly ruling out a more eclectic framework in which both the aggressiveness of workers and conventional economic variables might be influential. Further, tests by international monetarists have measured wage-push effects by including variables representing time lost in strikes rather than the dummy variables cited earlier. To the extent that workers achieve their wage aims by threats of strikes that are not actually carried out, wage push could exist but nevertheless be uncorrelated with strike variables. ${ }^{20}$ Unfortunately, this

17. Wiles, "Cost Inflation," p. 385; Stephen Marris, "Panel Discussion: World Inflation," in Claassen and Salin, eds., Stabilization Policies in Interdependent Economies, p. 303.

18. Aubrey Jones, for instance, argues that "a tightening of the supply of money is not, therefore, ... a solution to the problem of rising prices," in The New Inflation: The Politics of Prices and Incomes (London: André Deutsch, and Penguin, 1973 ), p. 39.

19. See in particular George L. Perry, "Determinants of Wage Inflation," especially table 4, p. 424, in which significant coefficients are found for a dummy for 1968 in France and for 1970 in Italy, West Germany, Sweden, and the United Kingdom (a 1968 dummy for Japan is only marginally significant). A similar approach was followed by Erich Spitäller, who found significant dummy coefficients in various periods for France, West Germany, and the United Kingdom; see "Semi-Annual Wage Equations for the Manufacturing Sectors in Six Major Industrial Countries," Review of World Economics, no. 2 (1976), pp. 300-37.

20. The most comprehensive tests of strike variables are presented in David Laidler, "Inflation-Alternative Explanations and Policies: Tests on Data Drawn from Six Countries," in Karl Brunner and Allan H. Meltzer, Institutions, Policies and Economic Performance (Amsterdam: North-Holland, 1976), pp. 251-306. 
problem makes it difficult to link puzzling episodes identified by significant coefficients on dummy variables to any quantifiable proxy for labor militancy.

\section{The Demand for and Supply of Monetary Accommodation}

International monetary effects and wage push are only two of the possible sources of inflation. A useful framework for analysis of the sources of inflation is to distinguish factors that create pressure on the central bank to "accommodate"-that is, to react by raising the money supply - and factors that help to explain why the central bank reacts as it does to these pressures. A "demand for monetary accommodation" is created by domestic demand shifts, domestic cost push, and demand and supply shocks from abroad. The "supply of monetary accommodation" by the central bank depends on the weights in its countercyclical reaction function, its own degree of independence from the government, and the extent of the government's attempts to influence its chances for reelection by manipulating the economy. ${ }^{21}$

\section{THE DEMAND FOR MONETARY ACCOMMODATION}

When the real money supply is held constant, an increase in domestic expenditures will tend to alter interest rates, whether its source is a change in consumer attitudes, business expectations, government spending, or tax rates. An increase in spending shifts the "IS curve" of intermediate macroeconomic theory to the right up a fixed "LM curve," and the central bank is forced to raise the money supply if it desires to offset part or all of the increase in interest rates that would otherwise occur.

Central banks may be under pressure not only from autonomous shifts in demand, but also from autonomous increases in wages and prices negotiated in the private sector, and from external supply shocks. At first glance the motivation for wage push may seem elusive, at least in a closed

Laidler has pointed out to me that strike variables were first used by British costpush proponents, not by international monetarists who were seeking to test the costpush hypothesis.

21. A more formal and extended presentation of this framework is developed in Robert J. Gordon, "The Demand for and Supply of Inflation," Journal of Law and Economics, vol. 18 (December 1975), pp. 807-36. 
economy, since prices are likely to be marked up over any autonomous wage increases achieved by workers, leaving real wages unchanged. But workers who "push" may achieve an increase in their real income relative to holders of assets with returns fixed in nominal terms, workers who have less market power, and profits of firms in the tradable-goods sector. Supply shocks-for example, crop failures or the formation of commodity cartels-are like any other type of cost push in creating problems for the monetary authorities, because a failure to accommodate will create unemployment, while accommodation may unleash an inflationary spiral if workers attempt to maintain their original real wage levels intact.

International capital mobility may embolden workers and others considering an autonomous push, since their own actions can directly induce a rise in the money supply by pulling in international reserves. In this case the push is automatically accommodated. Only when capital is less than perfectly mobile can the central bank attempt to sterilize part of the reserve inflow by open-market sales of its domestic assets, a restrictive rediscount policy, or an increase in the reserve requirements of commercial banks.

\section{THE SUPPLY OF MONETARY ACCOMMODATION}

\section{AND THE MONETARY REACTION FUNCTION}

The mere existence of pressure on the central bank does not imply that it will act either to accommodate or to resist. A central bank following Friedman's rule of a constant growth rate for the money supply would ignore such pressures entirely. More likely, a central bank will attempt to vary the growth of the money supply, or some other monetary instrument over which it believes it has more direct control, with the aim of maximizing a social-welfare function. Higher unemployment and inflation, and lower foreign-exchange reserves, are all evils that may be resisted by countervailing shifts in monetary policy.

Two sets of conflicts constrain the reaction of policymakers. First, even an idealistic attempt to maximize society's welfare collides with the incompatibility of short-run improvements in unemployment and in inflation, or in unemployment and in the foreign balance. Wage push and supply shocks allow no easy solutions, for a central bank must choose whether to resist their stimulus to inflation by contracting or to resist unemployment by expanding. 
Second, "idealistic" weights on target variables derived from economic theory may conflict with "popularity" weights motivated by political expediency. Evidence of a substantial lag of inflation behind changes in unemployment introduces a distinction, stressed by Lindbeck, between short-run targets, which maximize votes for an incumbent government's reelection, and long-run targets, which maximize economic welfare. ${ }^{22}$

\section{A Framework for Empirical Testing}

The general framework developed in the preceding section identifies a large number of variables upon which the behavior of the domestic money supply may depend-private and government expenditures, wage push, foreign prices, international reserves, domestic unemployment, and inflation. ${ }^{23}$ The aim of the empirical section is to determine whether any of the component hypotheses can be confirmed or denied, for the United States, for the "Other Seven" (the aggregate of seven major industrial countries besides the United States), or for any of the seven countries individually.

\section{CHAINS OF CAUSATION}

The central task of the empirical work is to estimate an equation in which the growth rate of the money supply is the dependent variable, and the set of independent variables includes those claimed above to be possible determinants of central-bank behavior. In addition to the money equation, equations with the growth rates of wages and prices as alternative dependent variables are estimated, in order to assess the role of autonomous wage push as a source of inflation. Table 1 lays out the expected pattern of signs on coefficients in equations explaining the behavior of the money supply and domestic wages, according to the various subhypotheses.

22. Assar Lindbeck, "Stabilization Policy in Open Economies with Endogenous Politicians," American Economic Review, vol. 66 (May 1976), pp. 1-19. See also William D. Nordhaus, "The Political Business Cycle," Review of Economic Studies, vol. 42 (April 1975), pp. 169-90.

23. Another factor, emphasized by Nordhaus, Lindbeck, and others, is the timing of elections. Although political dummy variables are included in the money equations estimated below, space limitations require that a full consideration of the political hypothesis be postponed for another paper. 


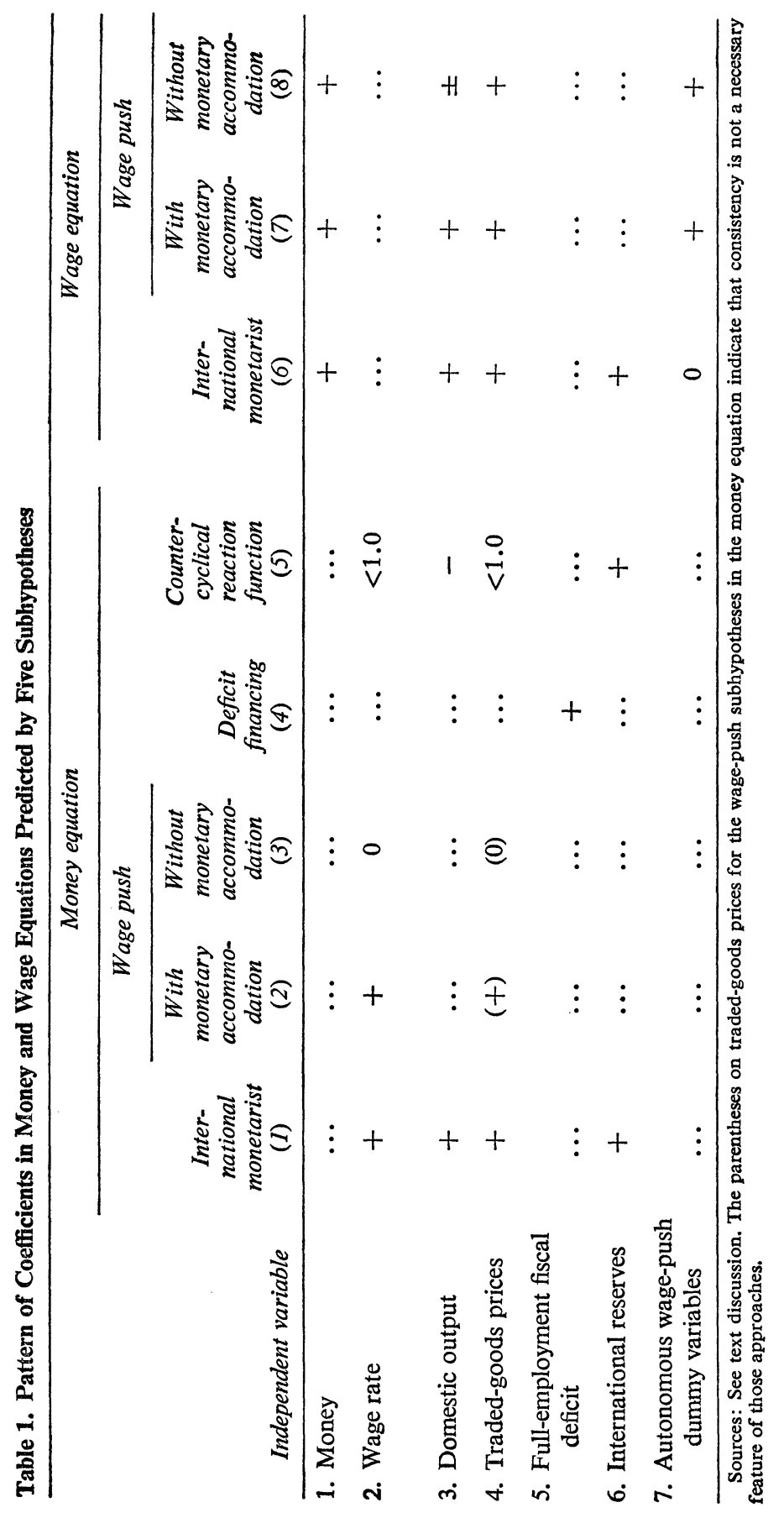


For instance, the first column lists the pattern of signs in the money equation predicted by the international-monetarist view. Consider the response of the economy to a foreign demand shock, the type of event that the international-monetarist approach blames for the worldwide acceleration of inflation in the late 1960s and early 1970s. Higher foreign demand stimulates both higher domestic output and higher tradablegoods prices. The simultaneous increase in reserves is partly a direct result of the trade surplus, and partly an indirect result of the higher demand for money induced by both the price and output effects. A money-supply equation should exhibit positive signs on current or lagged determinants of money demand, particularly domestic prices and output. Because of the focus here on the aftereffects of autonomous wage movements, the domestic price index is proxied in table 1 by the combination of tradable-goods prices and domestic wages. The role of international reserves is to identify the effect on money-supply growth of shifts in the demand for money caused by factors other than tradable-goods prices and domestic output and wages. The absence of a positive sign on international reserves in the money equation suggests the possibility that central banks succeed in varying their domestic assets to offset reserve flows and thus manage to sterilize some shifts in the demand for money. This would tend to deny that the supply of money is determined exclusively by the demand for money.

A positive sign on international reserves is consistent not only with the international-monetarist approach, but also with the countercyclical-activist view that an inflow of reserves allows a central bank to pursue its domestic price and output objectives in a more expansionary direction than would be possible if reserves were being lost. The countercyclical activists (column 5) would also expect that an increase in the growth rate of real output should lead to a reduction in the growth rate of the money supply. As for the variables reflecting nominal wages and tradable-goods prices, the coefficient in the money-growth equation can be positive but should be significantly smaller than unity (so that a wage or price acceleration is allowed to cut the level of real balances).

Some interpreters, particularly those identified with the internationalmonetarist camp, have tested a restrictive version of the wage-push approach which requires wage behavior to be entirely independent of any macroeconomic variables. A broader view is that autonomous forces are capable of shifting the rate of wage change, given domestic and world 
prices, domestic output, and monetary growth. Two versions of this broader wage-push approach are listed in separate columns in table 1: a wage push that is subsequently accommodated by the central bank (column 7), and a wage push that is not accommodated (column 8). The positive signs on line 7 in columns 7 and 8 represent the crucial autonomous wage-push effect. Since this autonomous influence is denied by most adherents to the international-monetarist view, a zero coefficient is entered in column 6 on line 7 .

But evidence of an autonomous wage push, in the form of significant positive coefficients on appropriate dummy variables in the wage equation, is not sufficient to validate the wage-push approach as a theory of inflation. First, the higher level of wage rates may cause a squeeze on profits rather than an increase in prices. This possibility may be greatest for a small, open economy and may result if the central bank does not provide the money to accommodate the wage increase. It is treated as a separate subhypothesis regarding the money equation in table 1 in the column reflecting wage push without monetary accommodation (compare columns 2 and 3 ). Not only is the coefficient on wage rates in the money equation equal to zero (line 2), but for consistency the money supply should not respond to increases in tradable-goods prices either (line 4) ${ }^{24}$

Shifts in domestic demand may lead to monetary accommodation if the central bank is attempting to stabilize interest rates. While private shifts in the IS curve are difficult to measure empirically, it is possible to include an estimate of the full-employment fiscal deficit as an additional variable in the money equation, with a sign expected to be positive if deficit financing has contributed to episodes of monetary acceleration, as in column 4.

The overview in table 1 suggests that distinguishing the internationalmonetarist view from the subhypothesis of wage-push with monetary accommodation may be rather difficult. Joint feedback between money and wage rates is admissible under either approach, as indicated by the positive coefficients on wages in the money equation and money in the wage equation. Nevertheless, the signs on coefficients in table 1 indicate that the framework can still yield interesting conclusions:

1. Zero coefficients on international reserves in the money equation would tend to raise the probability that central banks were able to sterilize

24. Since consistency is not a necessary feature of the policies of columns 2 and 3 , the entries on traded-goods prices in those columns are enclosed in parentheses. 
changes in the demand for money that attracted reserves, suggesting exceptions to the international-monetarist assumption that the domestic money supply is determined exclusively by the demand for money.

2. Zero coefficients on dummy variables in wage equations in periods when wage push is alleged to have occurred would tend to deny the relevance of the wage-push hypothesis and to confirm the negative verdict of previous empirical tests of that view produced by the international-monetarist camp.

3. Nonpositive coefficients on wage rates in the money equation, together with positive wage-push dummy coefficients, would tend to indicate that any episodes of wage push were not accommodated, a view that is consistent with columns 3 and 8 of table 1 .

4. Negative coefficients in the money equation on domestic output, or positive coefficients below unity on wages and tradable-goods prices, would tend to confirm the countercyclical-reaction approach and provide evidence against destabilizing accommodation.

5. Positive coefficients on the full-employment deficit would tend to confirm the deficit-finance subhypothesis without denying any of the others.

The pattern of signs in table 1 can be viewed from a broader perspective. First, the money equation provides a test of whether changes in the money supply are truly exogenous, dependent only on the fixed aims of the central bank, or the central bank reacts systematically to events in the economy (in which case econometric equations that treat the money supply as exogenous yield biased coefficients). Both international monetarists and wage-push proponents expect that the monetary authorities will behave passively, allowing an acceleration in monetary growth in response to a higher demand for money, whereas those who view the authorities as a central component of an activist stabilization policy hope that negative coefficients will emerge on the output ratio and zero or small positive coefficients will be attached to changes in nominal wages and tradable-goods prices.

\section{TESTS FOR EXOGENEITY AND FEEDBACK}

Empirical testing requires attention both to the signs of coefficients and to timing relationships. In an influential article Christopher Sims proposed testing for patterns of feedback between a pair of variables by running 
two regressions, with each as dependent variable and both leading and lagged values of the other as independent variables. ${ }^{25}$ Significant coeffcients on the leading values of a right-hand variable indicate that it is endogenous, influenced by feedback from the left-hand variable.

A second method, which was originally proposed by Granger and which Sims has recently implemented for the United States and West Germany, also involves estimation of a separate equation for each endogenous variable but substitutes lagged values of the dependent variable for leading values of the independent variables. ${ }^{26}$ Now a dependent variable is identified as exogenous if the coefficients on all the current and lagged values of the independent variables in its equation are zero. A separate equation is estimated for each variable of interest. For instance, the hypothesis that the money supply is truly exogenous, and not determined by feedback from any of the economic variables listed in table 1 , would require that all of the coefficients on current and lagged values of those variables be insignificantly different from zero in an equation with money as the dependent variable. Because all variables of interest are included on the right-hand side of each equation, some are bound to be endogenous. Once it is determined that a variable, say money, is subject to feedback because some right-hand coefficients in its equation are nonzero, it then becomes possible that the coefficients on money in other equations are biased. This limitation must be recognized in interpretations of individual coefficients in the regression results presented below.

Several factors lead to the choice of the second method in this paper. First, the inclusion of lagged dependent variables allows serial correlation to be purged, in contrast to the disadvantages of the arbitrary "prefiltering" performed by Sims in his oft-cited use of the first method. Second, the first method is extremely clumsy to use in multivariate applications, since both leading and lagging terms must be included for each independent variable; as a result, degrees of freedom are rapidly exhausted. Third, equations with leading variables cannot be subjected to postsample extrapolation experiments, which are often of interest to determine how well a given set of current and lagged right-hand variables account for

25. Christopher A. Sims, "Money, Income, and Causality," American Economic Review, vol. 62 (September 1972), pp. 540-52.

26. See C. W. J. Granger, "Investigating Causal Relations by Econometric Models and Cross-Spectral Methods," Econometrica, vol. 37 (July 1969), pp. 424-38. Sims' recent work is not yet available for distribution. 
movements of a dependent variable after the end of a given sample period. ${ }^{27}$

To control its length, the paper contains equations for only three dependent variables for each country, the nominal money supply, wage rates, and the deflator for gross national product (or gross domestic product), all expressed as quarterly rates of change. Primary emphasis is placed on the money and wage equations. A price equation is estimated only to examine the extent to which domestic prices responded during alleged episodes of wage push. ${ }^{28}$

\section{DETAILED SPECIFICATIONS}

The equation specifications have several important features. ${ }^{29}$

1. In light of recent evidence that U.S. wage behavior can be explained as well by the gap between actual $(Q)$ and potential $\left(Q^{*}\right)$ real GNP as by various unemployment concepts, I decided to use a single variable, the "output ratio" $\left(Q / Q^{*}\right)$, as a proxy for the effects of real output and labor-market conditions in the money, wage, and price equations. ${ }^{30}$ Because the level of money should be related to the level of $Q / Q^{*}$, the equation for the rate of change of money uses as an independent variable the rate of change of $Q / Q^{*}$. On the other hand, the traditional Phillipscurve hypothesis postulates that the rate of change of wage rates depends on the level of excess labor demand, so the level of $Q / Q^{*}$ was used in the equations for the wage rate and the price deflator.

2. There is no reason that an "automatic stabilizer" increase in the fiscal deficit caused by a recession should put pressure on the monetary authority. Thus as a proxy for the full-employment deficit, the fiscal-

27. I am grateful to Robert Hall for urging me to switch to the second method after a preliminary bout with the leading-variable technique.

28. The price equation includes two sets of current and lagged wage variables: (1) the contribution of the dummy variables in the wage equation, and (2) wage change minus the dummy contribution. If the two sets of coefficients are identical, then all wage changes alter prices in the same way, whereas a zero coefficient on the dummy contribution would indicate that the autonomous wage movements identified by the dummy variables did not influence price change at all.

29. Readers are referred to the data appendix, available from the author on request, for a detailed account of the construction of the data file developed for this project.

30. Robert J. Gordon, "Can the Inflation of the 1970s Be Explained?" BPEA, 1:1977, pp. 253-77. 
deficit variable that is entered into the money equations is the residual from a separate equation (not exhibited below) that explains the actual fiscal deficit as a function of a constant, seasonal dummies, and current and lagged real GNP.

3. The "basic equations" are uniformly estimated for the sample period 1958:3 to $1973: 1$. The first quarter is determined by the need to include lagged variables and by the 1957:1 starting date of the data file. The last quarter marks the initiation of the system of flexible exchange rates. Interesting features of the 1973-76 interval are identified both by examination of the residuals of a postsample extrapolation, and by reestimation of an auxiliary equation for the full 1958:3-1976:4 period. Shifts in coefficients between the basic and auxiliary equations can be examined for evidence of changes in structure in the period of flexible rates.

4. The auxiliary equations for the rate of change of the money supply all include as an additional variable the rate of change of the exchange rate between each country and the U.S. dollar, entered in the form of a multiplicative dummy equal to zero through 1973:1 and to itself thereafter.

5. Four lagged dependent and independent variables are included in the wage and price equations, and three lagged dependent and independent variables are included in the money equations.

6. For most countries the dependent variable in the money equation is $M_{1}$. Early investigations pointed to massive shifts between demand and time deposits in Canada and France in 1967-68 as a result of banking reforms, and so $\mathrm{M}_{2}$ was used for these two countries.

7. Preliminary results indicated that the coefficient on international reserves in the money equation should be allowed to shift at least once during the sample period. Thus separate coefficients on reserves are estimated in the money equations for 1958:3-1965:4 and 1966:1-1973:1, as well as for 1973:2-1976:4 in the auxiliary equations. The breaks for Canada are 1962:2 and 1970:2, corresponding to the end of the first experiment with flexible rates and the beginning of the second.

\section{THE ROLE OF DUMMY VARIABLES}

The use of dummy variables in the empirical results may require justification. The practice is generally accepted as legitimate when some a priori reason suggests treating a particular period as unique. But it can 
be questioned when the choice of time periods is arbitrary or based on a preliminary "peek" at the data. By this criterion the use of seasonal dummy variables in all equations qualifies on the a priori criterion, but the wage-push dummies cannot enter any such plea of innocence. Even if particular events that might have caused a wage push can be identifiedfor example, the Italian "hot autumn" of 1969-there is no a priori criterion to determine how long the effect on wage rates might have lasted. With simultaneous, centralized, nationwide bargaining, the entire effect might occur in one quarter. With other bargaining mechanisms, it could be spread over several quarters.

Because the precise timing of the wage-push dummies in some cases was of necessity determined by "peeking" at the data, separate versions of the wage equations with and without the wage-push dummies are exhibited. Although some readers might have preferred that the use of wage-push dummies be replaced by a detailed examination and discussion of individual residuals, this approach was rejected in order to avoid biasing other coefficients in an equation in which "true" specification involves dummies. In fact, the inclusion of dummy variables does generally alter the coefficients on other variables in the wage equations presented below.

\section{STRIKING FEATURES OF THE BASIC DATA}

Figure 1 displays four-quarter overlapping rates of change of money, wage rates, and the price deflator for the United States, for a weighted average of the Other Seven, and for the World, consisting of the United States and the Other Seven. ${ }^{31}$ The most striking aspect of the figure is the difference between the international-monetarist parable and the actual behavior of the average for the World and for the Other Seven. There appears to be only a very loose relation between World wage and monetary changes between 1958 and the end of 1972 . The rate of wage change was essentially constant between 1960 and 1966, and showed no response to the temporary acceleration of money in 1963-66. Further, monetary behavior appears able to explain little of the doubling of wage change between late 1967 and mid-1970, since the average rate of money growth during 1967-69 (7.1 percent) differed little from that in 1963-66 (6.8 percent). On the other hand, the lead of wage change relative to the monetary acceleration of 1970-71 suggests that at least part of the behavior of

31. The weights are current shares of real GNP in U.S. dollars. 


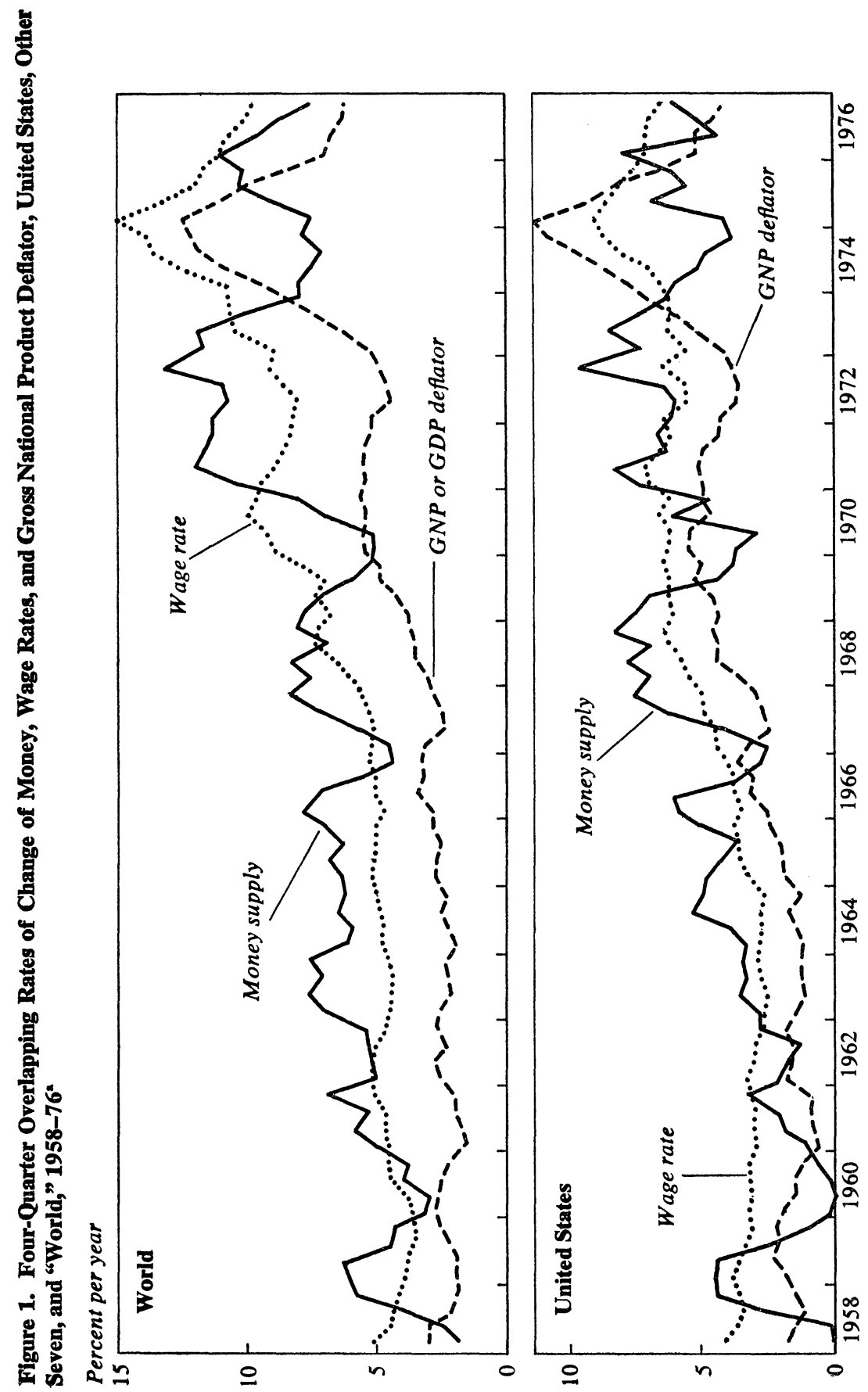




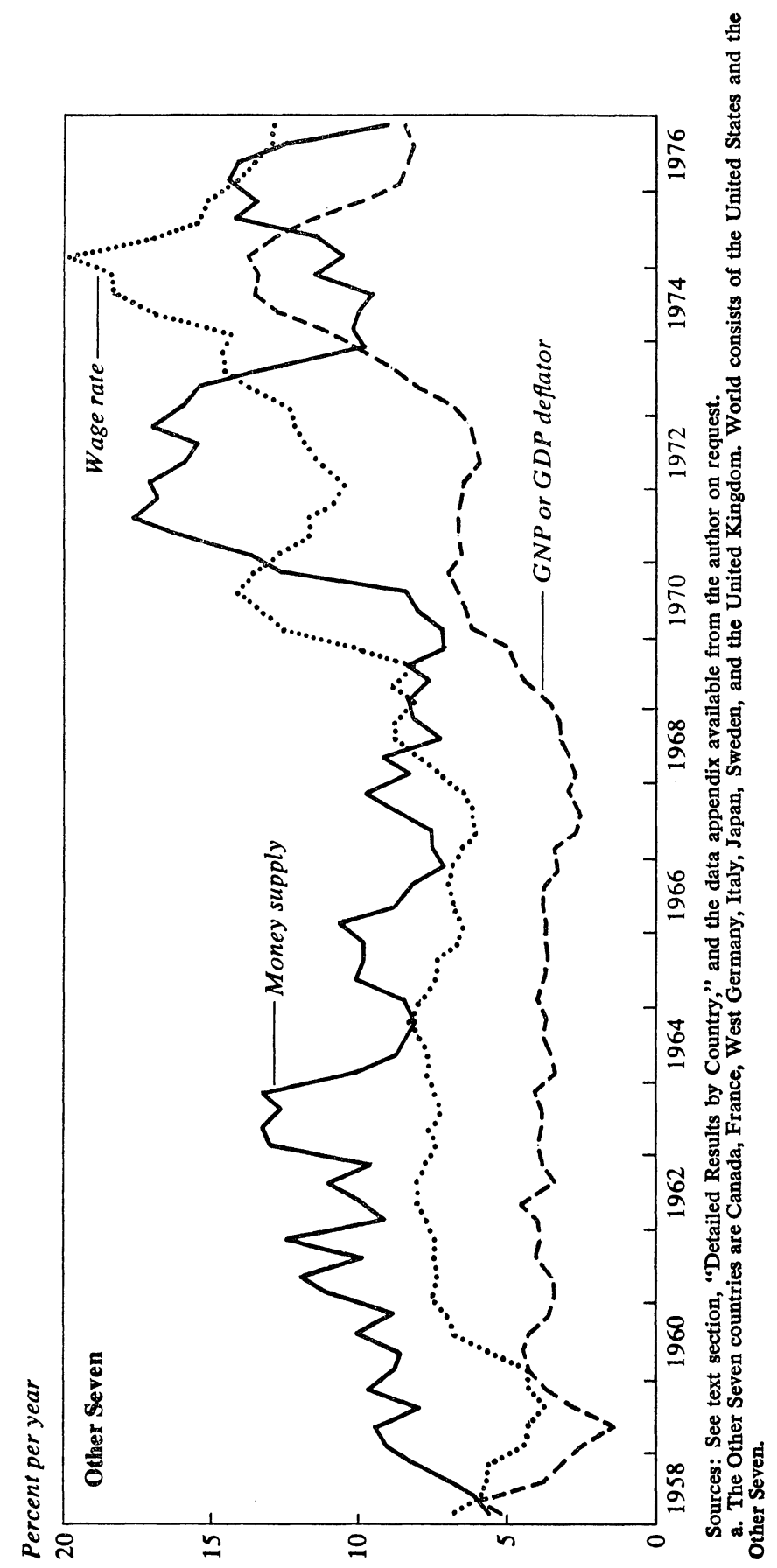


Table 2. Coefficients and $t$ Statistics from Two-Way Regressions on World Money and Wages, and on World Money and Prices ${ }^{\AA}$

\begin{tabular}{lcccc}
\hline & \multicolumn{4}{c}{ Independent variable } \\
\cline { 2 - 5 } $\begin{array}{c}\text { Lag on independent } \\
\text { variable and } \\
\text { regression statistic }\end{array}$ & $\begin{array}{c}\text { Money in } \\
\text { wage } \\
\text { equation } \\
(1)\end{array}$ & $\begin{array}{c}\text { Money in } \\
\text { price } \\
\text { equation } \\
(2)\end{array}$ & $\begin{array}{c}\text { Wage in } \\
\text { money } \\
\text { equation } \\
(3)\end{array}$ & $\begin{array}{c}\text { Price in } \\
\text { money } \\
\text { equation } \\
(4)\end{array}$ \\
\hline Lag & & & & \\
Current period & -0.043 & 0.016 & -0.371 & 0.197 \\
One period & $(-0.87)$ & $(0.38)$ & $(-0.87)$ & $(0.38)$ \\
Two period & -0.034 & 0.050 & -0.331 & -0.875 \\
& $(-0.68)$ & $(1.36)$ & $(-0.71)$ & $(-1.60)$ \\
Three period & 0.009 & 0.043 & 0.770 & -0.647 \\
Four period & $(0.16)$ & $(1.06)$ & $(1.58)$ & $(-1.35)$ \\
& 0.001 & 0.006 & 1.683 & 0.588 \\
Regression statistic & $(0.01)$ & $(0.15)$ & $(3.52)$ & $(1.12)$ \\
Sum of coefficients & -0.036 & 0.055 & -0.876 & 1.834 \\
& $(-0.85)$ & $(1.48)$ & $(-1.66)$ & $(3.47)$ \\
Standard error (percent) & 0.266 & 0.229 & 0.777 & 0.808 \\
\hline
\end{tabular}

Sources: See discussion in text.

a. All variables are one-quarter percent changes. All equations include in addition a constant term, three seasonal dummy variables, and four lagged values of the dependent variable. The sample period for all regressions in this table is $1958: 3-1973: 1$.

money in this period might be explained by passive accommodation to wage change.

Although the primary focus of this study is on chains of causation and timing relationships between money and wages in the eight individual countries, table 2 displays the results of simple regressions relating wage, price, and monetary rates of change. As in all regressions estimated in this paper, four lagged values of the dependent variable are included, so the dependent variable is considered exogenous and influenced only by its own past values if the coefficients on all of the independent variables are zero.

Table 2 explores the international-monetarist contention that the world inflation rate depends on previous values of world monetary growth. In fact, only in the price equation (column 2) is the sum of money coefficients statistically significant, although the sum of coefficients is much too small to be consistent with the long-run neutrality of world monetary change. But the results in column 1 do not appear at all consistent with a 
monetary explanation of wage behavior. Moreover, although the sum of coefficients on wages and prices in the two money equations is insignificant in columns 3 and 4, it is quite large, and one coefficient in each equation is very strongly positive. Thus the exogeneity of the world rate of monetary growth is not strongly supported, and the possibility is suggested that exogenous wage movements generated passive monetary accommodation.

Another interesting feature of figure 1 is the divergence of monetarygrowth rates in the United States and the Other Seven. While the growth rate of money accelerated in the United States between 1962 and early 1969, that in the Other Seven decelerated between late 1963 and early 1970. And though the explosive period of monetary growth in the Other Seven between late 1970 and early 1973 does correspond to a period of relatively rapid U.S. monetary growth, the previous period of acceleration in the United States during 1967-69 was accompanied by relatively low monetary growth rates in the Other Seven. Again this pattern is consistent with the hypothesis that the United States was not the sole engine of world monetary growth, and that domestic wage behavior within the Other Seven played some role in the 1970-71 monetary acceleration.

\section{Summary of Basic Results}

The signs and significance of several of the more interesting coefficients in wage and money equations for individual countries and the aggregate for the Other Seven are listed in table 3. The table starts with the United States and the weighted average of the Other Seven, and continues with the results for each of the Other Seven countries. The signs $(+, 0$, or -$)$ refer to the sums of coefficients of the independent variables, and the superscripts $a$ and $b$ indicate statistical significance (using a onetailed test) at the 10 percent and 5 percent level, respectively. A sign without a superscript stands at only the bare margin of significance, the 20 percent confidence level.

WAGE-PUSH, INTERNATIONAL RESERVES, AND MONETARY ACCOMMODATION

The basic message of the results is that, while no simple subhypothesis accurately describes the behavior of money and inflation in all of the 


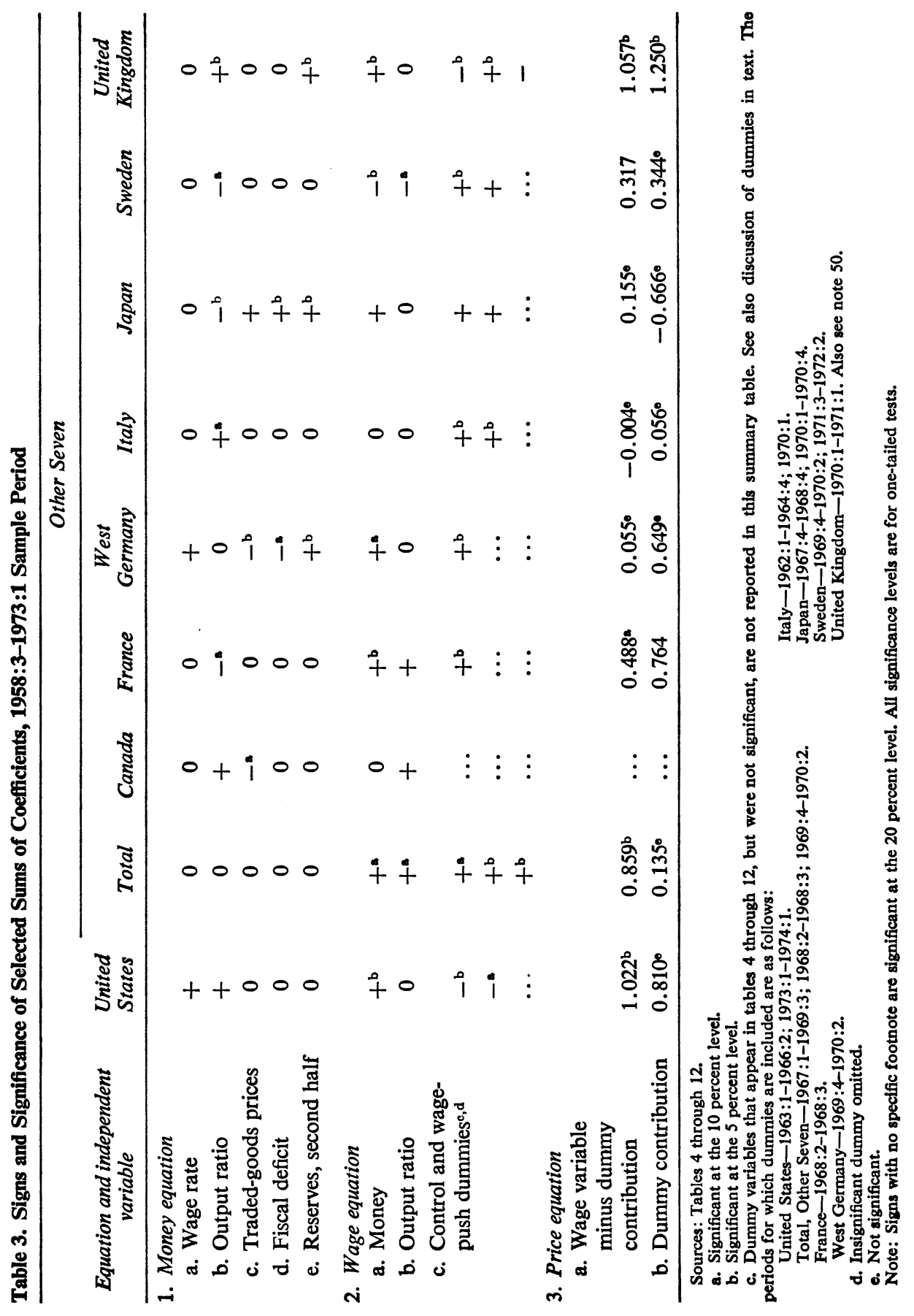


eight countries, nevertheless the international monetarists fare better than the wage-push group. The coefficient on international reserves in the second half of the sample period in the money equation (1966:1-1973:1) is strongly positive in three of the important countries, West Germany, Japan, and the United Kingdom, indicating that central banks in these countries were unable completely to sterilize shifts in money demand. Furthermore, in each of these three countries (as well as in the United States and France) money has a positive influence on the behavior of the wage rate. The explosion of growth in world reserves during the 1970-72 interval thus appears to have contributed to an acceleration of growth in the money supply and indirectly to an acceleration of wage growth.

The wage-push hypothesis appears to be alive and well as an explanation of wage rates, but not as a theory of inflation or of monetary growth. Large positive coefficients on wage-push dummy variables emerge in the price equation for various periods in the Other Seven average, and in France, West Germany, Italy, Sweden, and the United Kingdom taken separately. The inflationary impact of the autonomous wage movements is measured in a price equation that contains two wage variables (each entered as a current value and four lags): first, the actual rate of change of wages minus the contribution of the dummy variables in the wage equation, and second, the contribution of the dummy variables themselves. For the Other Seven as a group, the coefficient on the dummy contribution is close to zero, as compared with a coefficient on "normal" wage changes of close to unity. Only in the United Kingdom is the coefficient on the dummy contribution not only as large as the normal coefficient, but also statistically significant. In France, West Germany, Italy, and Sweden, the coefficient on the dummy contribution is larger than the normal one.

How can the generally small values of the sum of wage coefficients in the money equations be reconciled with the appearance of feedback from wages to money in the equation for the world as a whole (table 2, column 3)? The world response lies between the small response of the Other Seven and the large sum of coefficients for the United States. Thus passive monetary accommodation in the world appears to have been centered in the very country that exhibits no sign whatsoever of autonomous wage push. Only in the United Kingdom do the results display all of the ingredients required for wage push to be a valid theory not only of wages but also of continuing inflation; but, as discussed below, even this "victory" for wage push is tempered by the finding that the 1970 wage 
push in the United Kingdom was not autonomous at all, but rather appears to have been a postcontrols rebound.

In general, the behavior of monetary authorities in different countries has little in common, and no single subhypothesis receives strong confirmation. The Japanese appear to be inconsistent, pursuing a countercyclical policy relative to the output business cycle while simultaneously accommodating fiscal deficits. The Japanese money supply reacted positively to inflows of reserves, a result consistent with both the internationalmonetarist and countercyclical-activist approaches. Sweden exhibits countercyclical behavior, while money in Italy and Britain appears to fluctuate procyclically. Both the Germans and the Canadians are inconsistent, resisting higher prices of traded goods but allowing the growth rate of the money supply to rise in response to higher wage rates. A positive coefficient on a nominal variable does not indicate destabilizing behavior in the money equation unless its value exceeds unity; by this criterion only the United States and Sweden (and the United Kingdom in the extended sample period) exhibit a destabilizing response of money to wage change.

In several countries the international-monetarist case is bolstered by the significantly positive coefficients on money in the wage equation. Yet the results summarized in table 3 understate the monetary effect, because some of the procyclical correlation of money and wages is soaked up by the output-ratio variable. When the output ratio is omitted from the basic wage equation, the money coefficients become larger in several countries. $^{32}$ This result denies the extreme wage-push view that wage

32. The money coefficients and $t$ ratios (in parentheses), with and without the output-ratio variable, are as follows:

\begin{tabular}{lcccc} 
& \multicolumn{2}{c}{ With output } & Without output \\
United States & $0.258(3.04)$ & 0.327 & $(4.15)$ \\
Other Seven & $0.209(1.58)$ & 0.156 & $(1.11)$ \\
Canada & $-0.049(-0.43)$ & 0.019 & $(0.17)$ \\
France & $0.593(2.61)$ & 0.526 & $(2.48)$ \\
West Germany & $0.430(1.36)$ & 0.702 & $(2.52)$ \\
Italy & $0.179(0.77)$ & $0.212(0.94)$ \\
Japan & $0.172(1.12)$ & $0.171 \quad(1.00)$ \\
Sweden & $-0.260(-1.99)$ & $-0.024(-0.22)$ \\
United Kingdom & $0.652(2.89)$ & $0.706(3.55)$
\end{tabular}

The decline in the coefficient for the Other Seven is puzzling, in light of the increase in the average coefficient of the seven individual countries from 0.25 to 0.33 . 
claims are "picked out of the air" and are totally independent of market forces, but is consistent with a more eclectic view that both market forces and autonomous "push" episodes matter for wage behavior.

\section{Detailed Results by Country}

Tables 4 through 12, grouped together at the end of the paper for easy reference, present the detailed empirical results. There is one table for each country, and one for the aggregate of the Other Seven. The first two columns of each table present equations in which the quarterly rate of change in the money supply is the dependent variable, with the shorter sample period through 1973:1 in column 1 and the extended period through 1976:4 in column 2 . The next three columns present wage-rate equations, with the short sample period in column 3, and with control and wage-push dummy variables added in column 4 for the short period, and in column 5 for the extended period. Finally, a single equation for price change is presented in column $6 .{ }^{33}$

\section{THE UNITED STATES}

A vast amount of empirical work on "St. Louis equations" in the United States has treated the rate of growth of the money supply as exogenous in equations explaining the growth of nominal GNP. Sims' paper confirms the exogeneity of money in a simple bivariate test on the money supply and nominal income. ${ }^{34}$ This result appears to be repeated in column 1 of table 4 for the United States, in the sense that no sum of coefficients on any independent variable is significant, even at the 10 percent level. On the other hand, the sum of coefficients on the wage rate is very large, and one of the individual coefficients has a $t$ ratio of 3.6. A Tinbergen analysis indicates that the wage variable does contribute almost all of the explanation of the acceleration of monetary growth in $1964-68 .{ }^{35}$ It is the zigzag plus-minus pattern of the wage coefficients that reduces the significance of the sum of coefficients, suggesting

33. The set-up of table 6 , for Canada, is slightly different because no wage equations with dummy variables for the 1958-73 period were estimated for that country.

34. Sims, "Money, Income, and Causality," p. 547.

35. The contribution of the wage terms rises from an average of 1.23 percent per quarter in 1964 to 3.73 percent in 1968. 
that monetary growth responded in this period to the acceleration of wage growth, and less to the rate of growth of wages by itself. ${ }^{86}$

The most interesting features of the U.S. wage equations are the strong role of money and of dummy variables for guidepost and restraint periods. The significant negative coefficients on the guidepost dummies confirm earlier results, of Perry and others, and so does the pattern of the other dummy variables in general. When the effects of all three dummies for the 1971-75 period in the extended wage equation in column 5 are cumulated, the sum of 0.18 percent indicates that the rebound more than canceled the mild restraining influence of the controls. The bottom line in the table lists the postsample cumulative extrapolation errors for three of the equations. These errors are remarkably small, both relative to my previous work on "structural" wage and price equations, and compared to the results for some of the other countries.

\section{THE OTHER SEVEN}

The money supply in the Other Seven appears to have been exogenous, with no significant sum of coefficients on any independent variable. Despite the positive coefficients on international reserves in the money equations of several important countries, the money equation for the Other Seven bases its explanation of the 1970-73 money explosion (see figure 1) on a lagged response to changes in wage rates and tradablegoods prices. This in turn leads to horrendous postsample extrapolation errors, as the equation predicts huge rates of monetary growth, of 25 to 30 percent in 1974-75, in response to the 1974 acceleration in wage rates and tradable-goods prices. The large positive coefficient on the fiscal deficit also leads to an expectation of rapid monetary growth, in contrast to the deceleration that actually occurred.

The wage and price equations in the Other Seven are more reasonable and interesting. As in the United States, money and dummy variables play a relatively strong role, although here most of the significant dummy variables have positive coefficients which support the wage-push subhypothesis, rather than the predominantly negative coefficients observed for the United States. It is important to note that the significance of money

36. The coefficient on the fourth lag is strongly negative. The sum of coefficients on the current value and first three lags is 3.87 with a $t$ ratio of 2.53 . Figure 1 reveals the lead of wages relative to money in late 1965 , and the contemporaneous movements in late 1968, mid-1970, and early 1971. 
in the wage equation for both the United States and the Other Seven evaporates if the dummy variables are omitted (column 3 ). Thus one cannot claim both that dummy variables are unimportant or inappropriate and that money is an important determinant of wage change. The traditional Phillips-curve effect, in the form of a positive relation between the rate of change of wages and the level of the output ratio, shows up more strongly for the Other Seven than for the United States in column 4. Traded-goods prices also are more important, as would be expected.

The wage-push dummy variables are chosen for the same periods as in the major individual countries and are significant on lines $10 \mathrm{c}$ and $10 \mathrm{~d}$. But this lends little support to the wage-push hypothesis, because there appears to have been no significant positive impact of these autonomous episodes of wage change on the price deflator, or of wage rates in general on the money supply. The relatively strong positive impact of moneysupply growth on wages supports the international monetarists. But the direct effect of money on prices is negative. Combining the estimated role of money in the wage and price equations for the Other Seven indicates that more than half of the impact of money on wage change does not feed through to price change.

\section{CANADA}

The Canadian money equations differ from the others by splitting the reserves variable according to the dates when Canada terminated and reinstated floating exchange rates, and also by including the exchange rate as a variable throughout the sample period. Further, in light of previous results and the overall domination of the Canadian economy by the United States, each Canadian equation includes as an independent variable the corresponding quantity in the United States. ${ }^{37}$ The results yield few significant coefficients that would deny the exogeneity of the Canadian money supply. The influence of the U.S. money supply is surprisingly weak in light of the common periods of monetary restriction in the two countries in 1959-60, 1969-70, and 1974.

No dummy variables are included in the basic Canadian wage and price equations. U.S. wages and prices have relatively weak effects in the expected direction. In the extended wage equation through 1976 (column

37. See, for instance, Spitäller, "Semi-Annual Wage Equations for the Manufacturing Sectors." 
4), a dummy variable is included for the Canadian policy of wage and price restraints announced in October 1975. The equation, which relies on the U.S. wage and traded-goods prices for almost all of its explanation of Canadian wage behavior, attaches a strongly positive coefficient to this dummy variable. This perverse result apparently identifies the acceleration of wages in Canada relative to the United States that prompted the restraint program rather than the positive effects, if any, that the program had.

\section{FRANCE}

France appears to have pursued a relatively countercyclical monetary policy. The negative sums of coefficients on the output ratio and tradedgoods prices tend to confirm the OECD narrative of phases of French monetary policy which attributes restrictive measures introduced in 1963 and late 1968 to a reaction to the acceleration of inflation in those periods. Partially offsetting this verdict is a relatively large, albeit insignificant, sum of coefficients on wage rates. An inspection of the data indicates that the mid-1968 episode of autonomous wage increase was initially accommodated, but that within six months monetary policy had shifted to a stance of restriction.

Another interesting feature of the French money equation is the absence of any accommodation of reserve inflows. The expected positive correlation between money and international reserves in 1971-72 is offset by a dramatic negative correlation in 1968-70, when the initial monetary accommodation of the 1968 wage push caused massive reserve outflows, followed by a devaluation in August 1969, a period of tight money, and a reserve inflow. Another factor breaking the positive correlation between reserves and money was the mild restriction and a deceleration in monetary growth achieved by the French in late 1971, the period of maximum accumulation of reserves. ${ }^{38}$

The wage equation of column 4 introduces two dummy variables, the second of which reduces the standard error of the equation. The restraint dummy refers to the eight quarters of 1964 and 1965, when a mild form of incomes policy was in effect. ${ }^{39}$ The wage-push dummy is in effect in

38. This restrictive reaction to the capital inflow is noted in Organisation for Economic Co-operation and Development, Monetary Policy in France, Monetary Studies Series (Paris: OECD, 1974), p. 46.

39. Lloyd Ulman and Robert J. Flanagan, Wage Restraint: A Study of Incomes Policies in Western Europe (University of California Press, 1971), pp. 161-63. 
1968:2 and 1968:3 and reflects the impact of the June 1968 Protocole de Grenelle which resulted in a nominal wage increase of 11 to 13 percent in manufacturing in the aftermath of the May general strike.

The price equation tends to support the wage-push approach, since the contribution of the dummy-variable coefficients to price change was even greater than that of "normal" wage increases. But the wage-push episode did not lead to a continuing inflation because the final ingredient required for that development-a continuing accommodation by the central bank-was not present. By early 1969 the net influence of the countercyclical coefficients in the money equation-not just the negative coefficients on traded-goods prices and the output ratio, but also the positive coefficient on reserves-had swamped the influence of the positive coefficient on wages.

\section{WEST GERMANY}

The standard explanation of the explosion in German monetary growth between 1970:4 and 1973:1 is the flood of dollar reserves into the Bundesbank beginning in early 1970; and the advent of the flexible-rate system is usually cited as the factor that allowed the Germans to "regain control" of their money supply in early 1973. Indeed, the statistical significance of the second reserves variable is greater in the German money equation (table 8, column 1, line 8b) than it is for any other country. But an inspection of the other coefficients suggests that the story of German monetary movements is more complex than the simple internationalmonetarist story about a helplessly passive central banker drowning in dollars. Explaining the total acceleration in the four-quarter rate of change of money from 5.77 percent in 1970:3 to 13.41 percent in 1971:3, the equation assigns almost as much responsibility to the 1969-70 wage acceleration as to the 1970-71 inflow of reserves. ${ }^{40}$ This single episode of monetary accommodation stands in sharp contrast to the evidence that during most of the rest of the sample period the central bank operated according to a simple countercyclical reaction function, inaugurating a restrictive policy when the inflation rate began to accelerate. The equation picks up this countercyclical behavior by assigning a large negative coefficient to the change in traded-goods prices, which makes a substantial

40. Over the same period the contribution of the wage terms to the four-quarter rate of change of money rises by 5.23 percent, and of the reserve terms by 6.72 percent. Since this overexplains the actual acceleration, the contribution of the other terms decreases. 
negative contribution in each of the phases labeled as "restrictive" by the OECD (1959-60, 1965-66, and 1969-70).41

The large underprediction in the postsample extrapolation of the German money equation is a less extreme version of the Canadian problem; when a negative coefficient is assigned to the change in tradable-goods prices, a large negative growth rate of money is predicted in 1974. The extended money equation exhibits substantial shifts in coefficients as it struggles to explain the 1974 experience, providing evidence of a structural shift in German monetary policy when the era of flexible exchange rates began in early 1973 .

Two dummy variables are included in the German wage and price equations. A restraint dummy is in effect in 1967-69, a period during which union leaders are claimed to have agreed to modest wage increases in the interests of economic stabilization. ${ }^{42}$ Then a "reentry," or wagepush, dummy covers the three quarters 1969:4-1970:2. The restraint dummy is insignificant, but the wage-push dummy is very large, contributing a cumulative wage increase of almost 6 percent in column 4 and more than that in column 5 .

Did the 1969-70 episode contribute to a continuing acceleration of inflation? The coefficient on the wage-dummy contribution in the price equation is relatively large, but at a very low level of significance. More important may have been the positive effect of the wage increases on monetary growth, and of money growth on price behavior. Overall, the results seem to suggest that the inflow of dollar reserves was not the sole cause of the German monetary explosion of 1970-72, and that at least some of the responsibility rests with domestic wage developments.

\section{ITALY}

Although significance levels are low, most variables in the basic Italian money equation are positive, indicating an accommodative rather than

41. OECD, Monetary Policy in Germany, Monetary Studies Series (Paris: OECD, December 1973), pp. 43-50.

42. Ulman and Flanagan, Wage Restraint, pp. 186-91. See also Gerhard Fels, "Inflation in Germany," in Krause and Salant, eds., Worldwide Inflation, pp. 619-20. Herbert Giersch dates the voluntary restraint back to a meeting between the German Council of Economic Advisers and representatives of the trade unions and the employers' associations on June 17, 1965, in A Discussion with Herbert Giersch: Current Problems of the West German Economy, 1976-1977 (American Enterprise Institute, 1977), p. 6. 
countercyclical monetary policy. An acceleration of the rise in wages, output, and traded-goods prices, and a larger fiscal deficit all appear to have stimulated monetary growth. In contrast to West Germany there is no accommodation of reserve inflows in 1971; quarterly rates of monetary growth in Italy were lower in every quarter of 1971 than in the corresponding quarter of the preceding "wage-push" year, 1970. A structural change appears to have occurred in 1973, since the equation predicts more than double the monetary growth that actually took place after the end of the sample period.

The large and significant coefficients on the dummy variables in the Italian wage equations suggest that the Italian data are congenial to a wage-push interpretation. The first dummy variable applies to the period in the early 1960s often described by the term "wage explosion." 43 The second applies to the single quarter when the wage increases following the "hot autumn" of 1969 took effect.

But, although wage push helps explain wages in Italy, the wage-push hypothesis suffers in the price equation, since wage increases had no influence at all on price increases. Nor did wage growth have a substantial impact on the monetary authorities. The Italian central bank appears to have behaved in a destabilizing procyclical manner, but more in response to domestic output than to wage rates. The absence of price response to the 1970 wage push is confirmed by an inspection of the data: the deflator for the Italian GNP exhibits a rate of increase in the first three quarters of 1970 that is almost identical to that of the same period in 1969. Perhaps the most surprising aspect of the Italian inflation performance was the absence of any acceleration during the entire 1969-72 period. Economic recovery between 1966 and 1969 had already caused a substantial acceleration in wage and price change before the "hot autumn."

Since 1973, Italian wage increases have been considerably more rapid than can be explained by the coefficients in the 1958-73 wage equation. A comparison of columns 4 and 5 of table 9 indicates that the coefficient on traded-goods prices has become larger and much more significant. More than those in most other countries, workers in Italy have fought to preserve their real wages in the face of a spiral in traded-goods prices caused by the food and oil supply shocks of 1973-74, and by the depreciation of the lira beginning in mid-1975. But the high positive coefficient

43. Ulman and Flanagan, Wage Restraint, pp. 202-03, include the interval $1961: 3-1963: 2$ in their description of the "wage explosion." 
on monetary growth in the wage equation when it is extended through 1976 suggests that the central bank may have considerable leverage over the behavior of wage rates given changes in traded-goods prices.

\section{JAPAN}

Japan seems to be the model case in which monetary policy responded primarily to the growth rate of international reserves. Most analyses of Japanese postwar monetary policy cite deteriorations in the balance of payments as the single factor behind episodes of monetary restriction. ${ }^{44}$ The basic money equation in table 10 , column 1 , is consistent with this overall interpretation, with the largest positive sum of coefficients on reserves of any country.

But there seems to be more to an explanation of monetary behavior than a simple reserves effect. Beyond that, the money supply appears to have responded strongly in a countercyclical direction to output fluctuations. In fact, the accommodation of reserve inflows in 1971 might not have been so extreme had the economy not been experiencing a growth recession in that year, with the trough of the output ratio occurring in 1971:4.

Accounts of Japanese wage and price behavior appear unanimous in denying any role for wage push. ${ }^{45}$ Perry's test for autonomous wage change in 1968 yielded a positive coefficient on a dummy variable for that year but at a low level of significance. ${ }^{46}$ Perry's conclusion is confirmed in table 10, where dummy variables for 1968 and for 1970 are positive but insignificant. Further, the absence of any positive impact of wage change on monetary growth argues against any lasting effect of autonomous wage movements on the inflation rate.

The pattern of postsample extrapolation errors is consistent with that in other countries and can be interpreted in light of shifts in coefficients

44. OECD, Monetary Policy in Japan, Monetary Studies Series (Paris: OECD, December 1972), p. 58. See also Gardner Ackley with collaboration of Hiromitsu Ishi, "Fiscal, Monetary, and Related Policies," in Hugh Patrick and Henry Rosovsky, eds., Asia's New Giant: How the Japanese Economy Works (Brookings Institution, 1976), pp. 169-71. Ackley and Ishi argue that it was the balance of payments alone, not domestic overheating of inflation, that guided the timing of the monetary authorities.

45. See ibid., p. 176. Also Ryutaro Komiya and Yoshio Suzuki, "Inflation in Japan," in Krause and Salant, eds., Worldwide Inflation, pp. 303-48.

46. Perry, "Determinants of Wage Inflation around the World," table 6, p. 427. 
when the sample period is extended. The huge overprediction of monetary growth after 1973 is accounted for largely by the positive coefficient on traded-goods prices, which suggests erroneously that the oil shock would be accommodated rather than resisted. Further, the countercyclical behavior during 1958-73 leads to the expectation that the central bank would do more than it actually did to counteract the unprecedented 197375 drop in the output ratio.

\section{SWEDEN}

The main feature of the Swedish monetary equation is a countercyclical output effect, similar to but larger in size than that in the corresponding Japanese equation. The recent problems of the Swedish economy, leading to the August 1977 devaluation, may date back to the unique Swedish response to the 1974 supply shocks and worldwide recession. In contrast to most countries, which failed to pursue vigorous monetary policies to counter the recession, the four-quarter rate of change of money in Sweden reached postwar peaks, around a 30 percent annual rate of growth, throughout the 1974:3 to 1975:2 interval. ${ }^{47}$ As in the case of Canada and Germany, a negative coefficient on traded-goods prices in the sample period 1958-73 causes a postsample prediction of a drop in the money supply, in contrast to the acceleration that actually occurred and that shifts the coefficient on traded-goods prices to a positive value in the extended money equation.

Appropriately enough, Swedish wage behavior appears to adhere to the Scandinavian model of the international transmission of inflation. ${ }^{48}$ The elasticity of wage change to changes in world prices is very large in all of the wage equations. A set of three dummy variables was introduced into the wage equations. First, following Perry's lead, a wage-push dummy was introduced for 1970. Second, a dummy was included for the subsequent year, to determine whether price restraint had any effect on wage behavior. ${ }^{49}$ Finally, a "reentry" dummy was entered to test whether any restraining effect in 1971 was offset in 1972.

47. This statement is equally valid for $M_{1}$ and $M_{2}$. The four-quarter rate of change of $M_{1}$ peaked at 27.2 percent in 1974:3 and that for $M_{2}$ at 34.0 percent in the same quarter.

48. Edgren and others, "Wages, Growth and the Distribution of Income," and Aukrust, "Inflation in the Open Economy."

49. Lars Calmfors, "Inflation in Sweden," in Krause and Salant, eds., Worldwide Inflation, p. 530. 
The signs are positive on all three dummy variables in the wage equations, and significant in the case of the first and third, indicating that wage change was faster than otherwise would have been expected during the entire 1970-72 period. The unsatisfactory forecasting performance of the 1958-73 wage equations is a consequence of the implausibly high coeffcient on traded-goods prices, which leads to the prediction of much faster wage increases in 1973-75 than actually occurred. The coefficient drops to a much more reasonable level in the extended equation in column 5. All wage equations exhibit the same negative coefficients on money and the output ratio, perhaps justifying the skepticism of Scandinavian economists about the monetarist approach, but suggesting a puzzle that requires further research.

\section{UNITED KINGDOM}

The results for the United Kingdom are perhaps the most interesting of all, and offer so many positive and significant coefficients that both international monetarists and wage-push proponents will be pleased that their approach is vindicated, but dismayed that the opposite framework is validated as well! The basic money equation indicates significant accommodation of both output changes and inflows of reserves. The monetary authority appears to have behaved in a destabilizing manner, increasing the amplitude of the output business cycle until forced by a balance-ofpayments constraint to shift to a restrictive policy.

The selection of dummy variables for the wage and price equations is designed to test whether alleged episodes of wage push actually represented a rebound in the aftermath of the various periods of wage freeze and restraint. Periods of applicability of the various dummy variables are those selected by the Economist as subject to a wage "freeze," "restraint," or "reentry." In addition, a special dummy is included for the 1970 episode that has made wage push a byword among British economists. Indeed, autonomous movements during control and reentry periods appear to be important in explaining British wage behavior. Further, the behavior

50. "Faith, Five Hopes, and Cassandra," Economist (July 23, 1977), p. 75. The freeze dummy is in effect in $1961: 3-1961: 4 ; 1966: 3-1966: 4 ; 1972: 4-1973: 1$. The restraint dummy is in effect in $1962: 1-1963: 1 ; 1967: 1-1969: 4 ; 1973: 2-1974: 1$; $1975: 2-1976: 4$. The reentry dummy is in effect in $1963: 2-1964: 1 ; 1970: 1-1970: 4$; 1974:2-1975:1. 
of prices appears to have corresponded to that of wages, in contrast to the absence of price response to wage dummy variables in most other countries. And as final icing to the wage-push cake, the coefficient on wages in the money equation is positive and extremely large in the extended sample period.

But international monetarists might respond that though the icing may be impressive the cake within is cardboard. Somewhat remarkably in light of the antimonetarist orientation of many British economists, the influence of money on wage behavior is stronger than it is in any other country. Moreover, the 1970 wage-push episode does not appear to represent any profound sociological phenomenon, but simply an attempt to catch up for losses in real income during the preceding period of restraint. Because the restraint dummy is in effect for so many quarters (line 10b), the cumulative effect of all the dummy variables taken together is strongly negative, implying that total wage change during 1958-73 was 26 percent less than would have been expected on the basis of the contribution of the other coefficients. ${ }^{51}$

As further support for the monetarist case, the equations for the United Kingdom clearly indict the Bank of England as the major culprit in the 1974-76 British wage explosion. Like workers in all other countries except the United States and West Germany, British workers tried to maintain their real wages in the face of the 1973-74 increases in tradedgoods prices. The central bank then responded by accommodating these wage increases, and this monetary acceleration fueled a further increase in the rate of wage growth.

\section{Conclusion}

Despite the length of this paper, it should be viewed as a preliminary effort. The episodes of autonomous wage changes captured here by dummy variables may be attributable partially to factors unique to each country - tax changes, increases in the minimum wage, or changes in

51. Another serious defect in the wage-push argument is evident if account is taken of changes in the tax rate, a variable not included in this study. Large tax increases in 1967-69 would have justified a wage push by British workers even if wage restraint had not been in effect. See H. A. Turner and Frank Wilkinson, "Real Net Incomes and the Wage Explosion," New Society, vol. 17 (February 25, 1971), pp. 309-10. 
unemployment compensation systems. Moreover, the results may be sensitive to the particular wage series used in each country, and to errors in measuring wages. The attempt to fit a single money equation to the period 1958-73 overlooks the likelihood that monetary regimes may change. Further explorations into the behavior of monetary authorities will require experiments to reveal such changes, and should be conducted on a variety of monetary aggregates and bases. Nevertheless, several interesting conclusions do emerge from the results presented here.

The paper began with three quotations setting out the conflict between the international-monetarist and wage-push explanations of the acceleration of world inflation during the latter part of the era of fixed exchange rates. Which of the quotations survives the confrontation with the data?

Harry Johnson attributed the acceleration of world inflation ultimately to U.S. monetary expansion. Table 2 confirms that world inflation is significantly influenced by the world rate of monetary growth, to which the United States contributes about half. U.S. monetary growth appears to have had a significant influence on the growth rate of U.S. wages, and U.S. prices then responded to wage changes with an elasticity of unity. The rate of wage growth in the Other Seven appears to have accelerated in 1969-70, well before the 1970-71 acceleration in monetary growth there, but this does not rule out a causal role for U.S. monetary behavior. The statistical results attribute about two-thirds of this wage acceleration in the Other Seven to the influence of a high output level and an acceleration in the rise of world prices of tradable goods, both of which were caused partly by the prior U.S. monetary acceleration. As in the case of the United States, these wage increases in the Other Seven were then passed on as domestic price increases, and the domestic price level in the Other Seven was also pushed up directly by higher world prices of tradable goods.

Nicholas Kaldor prefers to attribute the acceleration of world inflation to a wage push caused by trade-union militancy. The results here provide little support for this wage-push interpretation. About one-third of the 1967-70 acceleration in wage growth in the Other Seven is attributable to the contribution of the dummy variables in the wage equation for the Other Seven. But, as the Harberger quotation points out, the other macroeconomic effects required for wage push to be a source of a continuing inflation were absent. The portion of the wage acceleration contributed by the wage-push dummy variables in the Other Seven did not feed through 
into price change. ${ }^{52}$ Further, there is no sign of the passive accommodation of wage change by monetary authorities required if an inflation initiated by wage push is to continue. A positive effect of wages on monetary behavior is close to statistical significance only in the United States, where there was no sign of any autonomous wage push. It is fitting that the wage-push hypothesis comes closest to fulfilling its macroeconomic requirements in the United Kingdom, where it has received such widespread attention; but even so the autonomous upsurge of wage change in 1969-70 appears to have represented a rebound in the aftermath of wage controls and restraint rather than a spontaneous event.

Is control of the money supply sufficient to control inflation? Money growth has a significantly positive impact on wage growth in four major countries making up 72 percent of the 1976 GNP of the eight countries considered here..$^{53}$ Not only does this tend to deny the contention of some wage-push proponents that wage claims are numbers "picked out of thin air," but it also supports the international-monetarist position that control of world monetary growth is a crucial requirement in the determination of the world inflation rate. A qualification is that in the remaining four countries the effect of money on wages is weak or nonexistent. A further qualification is that the estimated elasticity of wages with respect to money is small, and that of prices with respect to money is smaller still. Finally, this effect of money on prices apparently operates in conjunction with the effect of money on output.

The results indicate that the major competitor to the internationalmonetarist approach as an explanation of world monetary growth is not the wage-push hypothesis, but rather the countercyclical-reaction function. It does not appear to be true, as proponents of the internationalmonetarist view contend, that the money supply in these countries is automatically set equal to the demand for money by international movements of capital. Instead, in the money equations for most countries there are negative coefficients on either tradable-goods prices or the domestic output ratio, two important positive determinants of the demand for money. Further, the positive coefficients on international reserves in the

52. For the Other Seven the dummy contribution had essentially a zero sign in the price equation, and in all countries other than the United Kingdom its coefficient was insignificantly different from zero.

53. The four countries are the United States, France, West Germany, and the United Kingdom. See note 32, which presents estimates of the money coefficients in the wage equation when the output-ratio variable is omitted. 
money equations for several countries are consistent with the countercyclical-reaction approach as well as the international-monetarist view. Almost all countries experienced periods of monetary restriction as central banks responded to some combination of buoyant growth in output, imported inflation, and reserve outflows.

The study reveals differences among countries in the behavior of money and wage rates that are as interesting as their similarities. Today's dichotomy between "healthy" nations like West Germany and Japan, caught in a virtuous circle of appreciation and decelerating inflation, and "sick" nations like Italy and the United Kingdom (pre-1977), caught in a vicious circle of depreciation and persistent inflation, shows up in differences in behavior before the advent of flexible exchange rates in 1973. Growth cycles in the money supply in Germany and Japan appear to have followed a countercyclical-reaction pattern, whereas accommodation was the rule in Italy and the United Kingdom.

The results provide little support for the idea that central banks indirectly cause wage push through prior episodes of accommodation. In fact, the largest coefficient on wages in a money equation occurs in the case of the United States, which exhibits no evidence of wage push at all. On the other hand, one can apparently pick today's healthy and sick nations reasonably well by the response of wage rates to traded-goods prices. $^{54}$ This in turn may reflect in part a guess by trade unions in the sick nations that any attempt to maintain real wages in the face of the 1974 supply shocks would be accommodated by central banks.

The paper provides ample support for Lucas' criticism of econometric models as forecasting devices. ${ }^{55}$ Policy regimes have changed in the face

54. Compare the traded-goods coefficients in the extended wage equation in each of the tables. The size of the coefficients appears to be a rather accurate inverse indicator of the current economic health of the major economies:

$\begin{array}{ll}\text { Italy } & 0.753 \\ \text { Sweden } & 0.682 \\ \text { United Kingdom } & 0.404 \\ \text { France } & 0.323 \\ \text { Canada } & 0.282 \\ \text { Japan } & 0.179 \\ \text { United States } & 0.029 \\ \text { West Germany } & 0.025\end{array}$

55. Robert E. Lucas, Jr., "Econometric Policy Evaluation: A Critique," in Karl Brunner and Allan H. Meltzer, eds., The Phillips Curve and Labor Markets (North-Holland, 1976), pp. 19-46. 
of novel events like the 1974 supply shock. In the case of almost every country, money equations estimated for the 1958-73 interval make huge forecasting errors during 1973-76; it appears that the response of the monetary authorities to changes in traded-goods prices shifted in the face of the striking price increases of 1974. Further, the dramatic contrast between the volatility of changes in the wage rate in some of the Other Seven countries and the sluggish changes exhibited by the United States reminds us that we all take for granted characteristics of the U.S. economy that depend ultimately on its labor-market institutions and that would change dramatically if those institutions resembled the ones in Europe and Japan.

Tables 4 through 12 follow. 


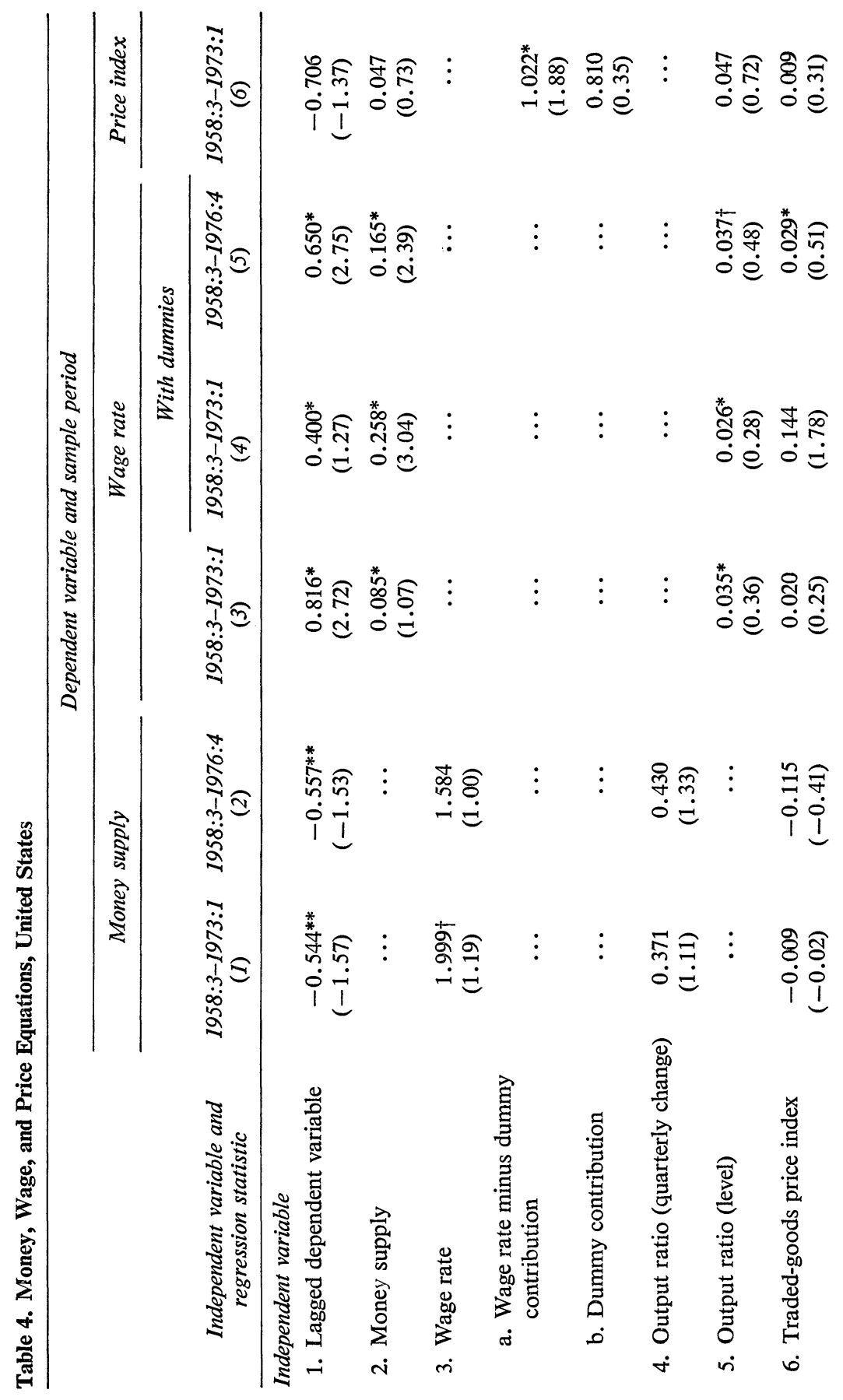




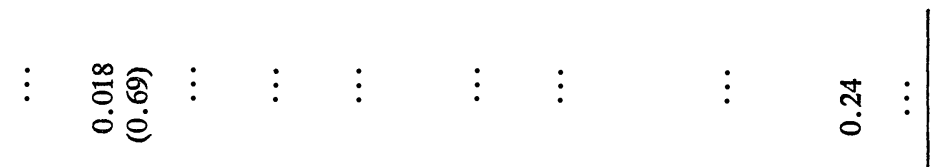

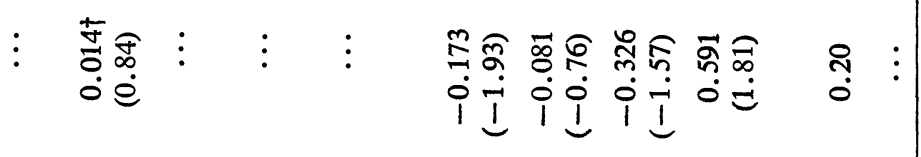

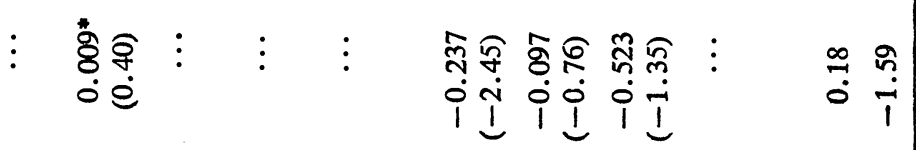

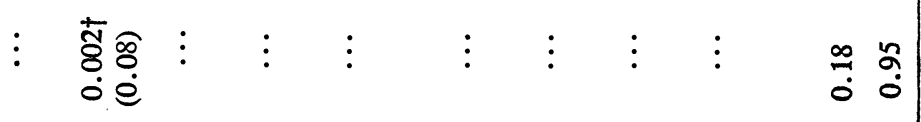

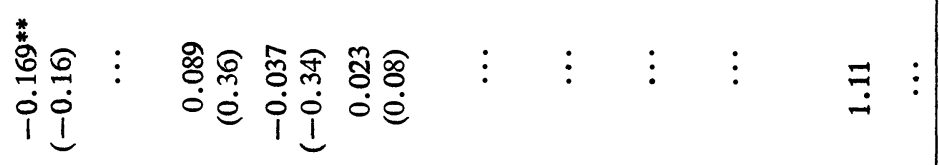

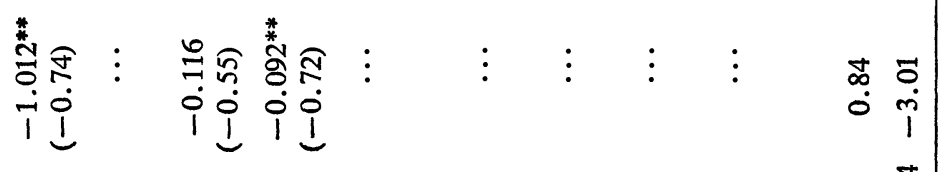

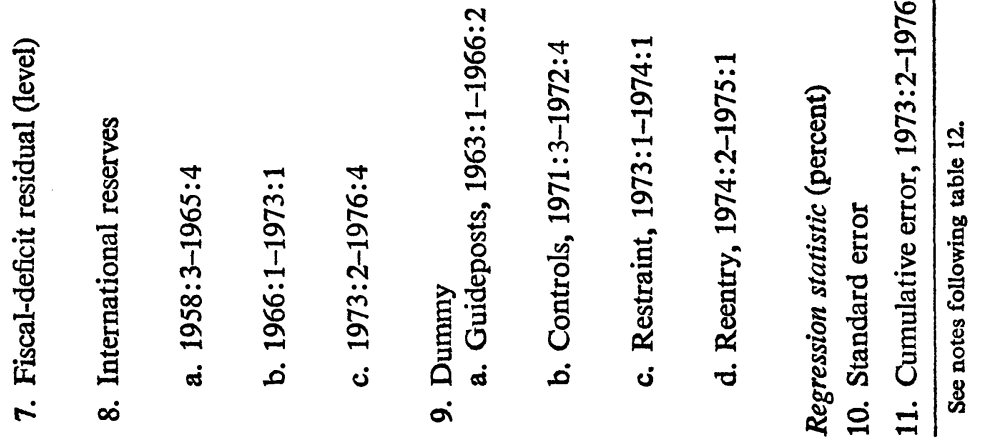




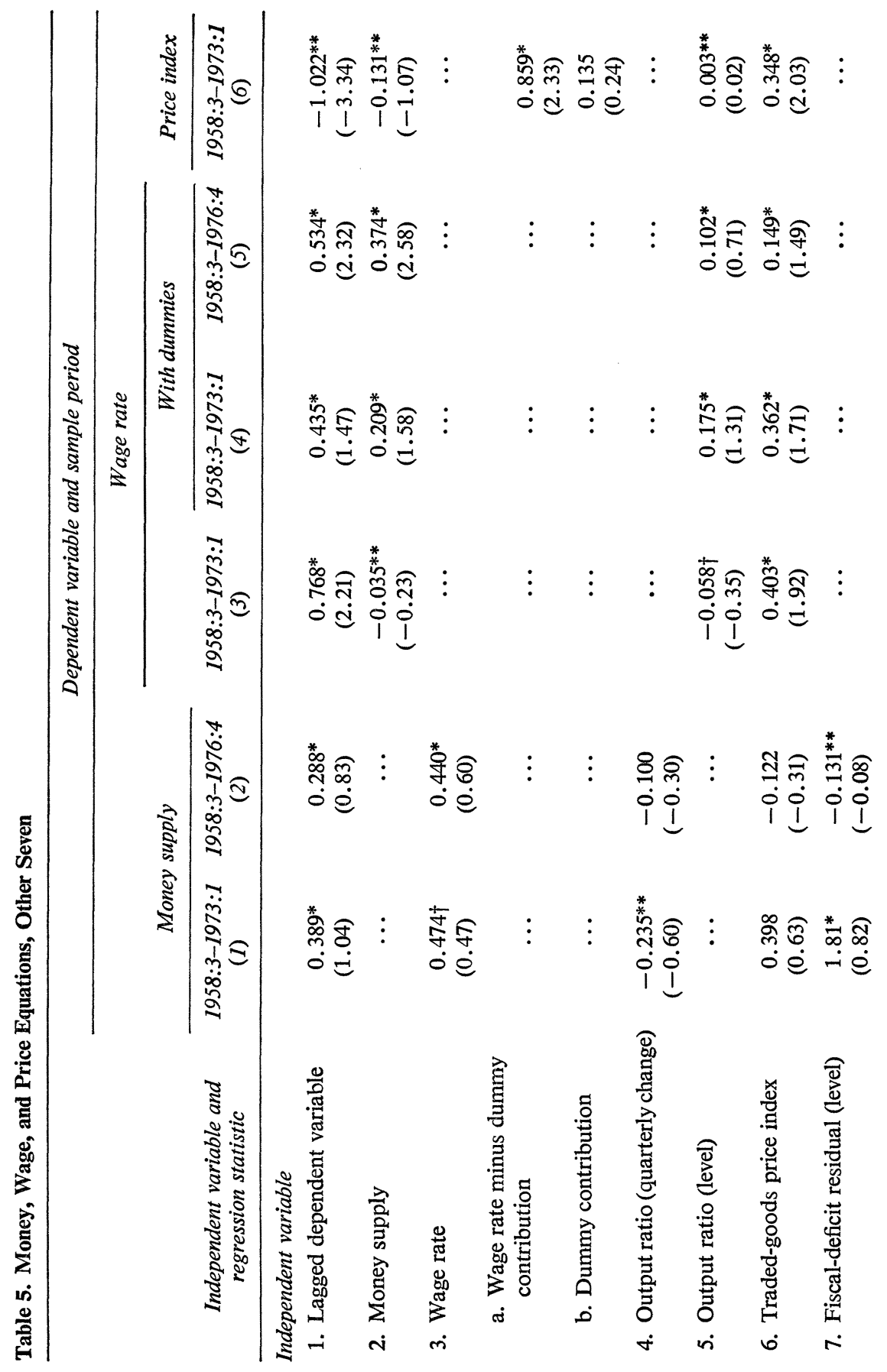




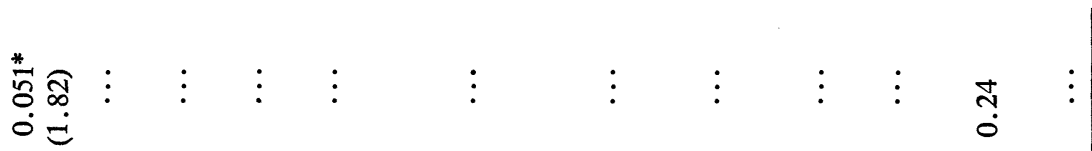

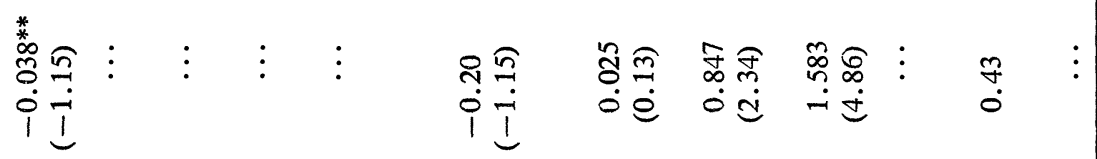

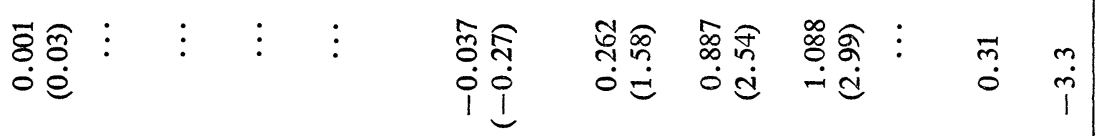

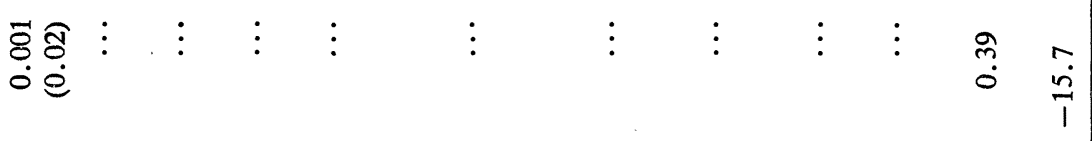

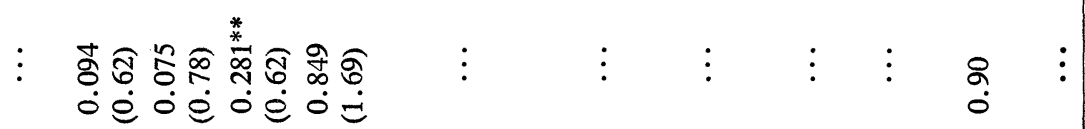

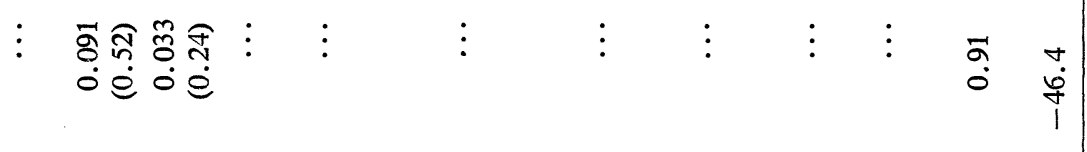

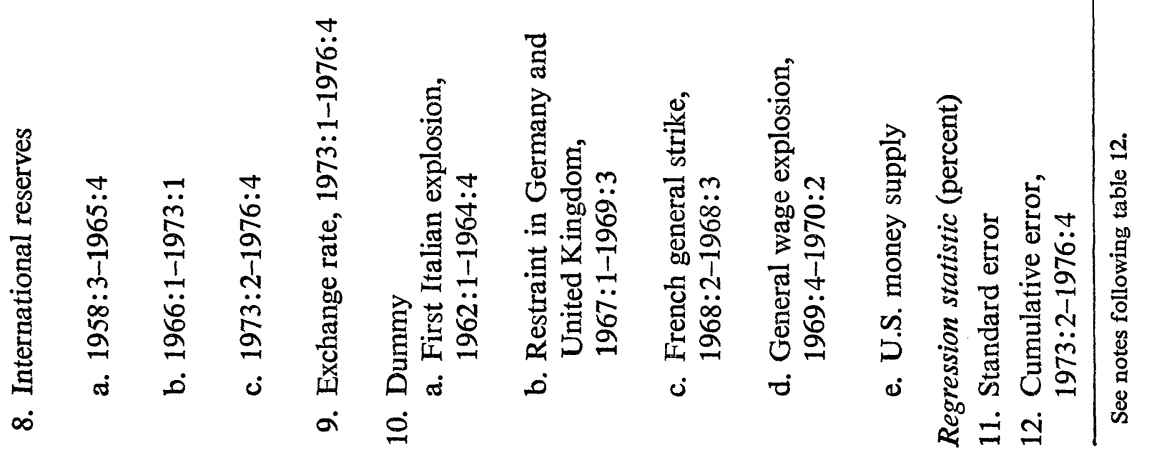




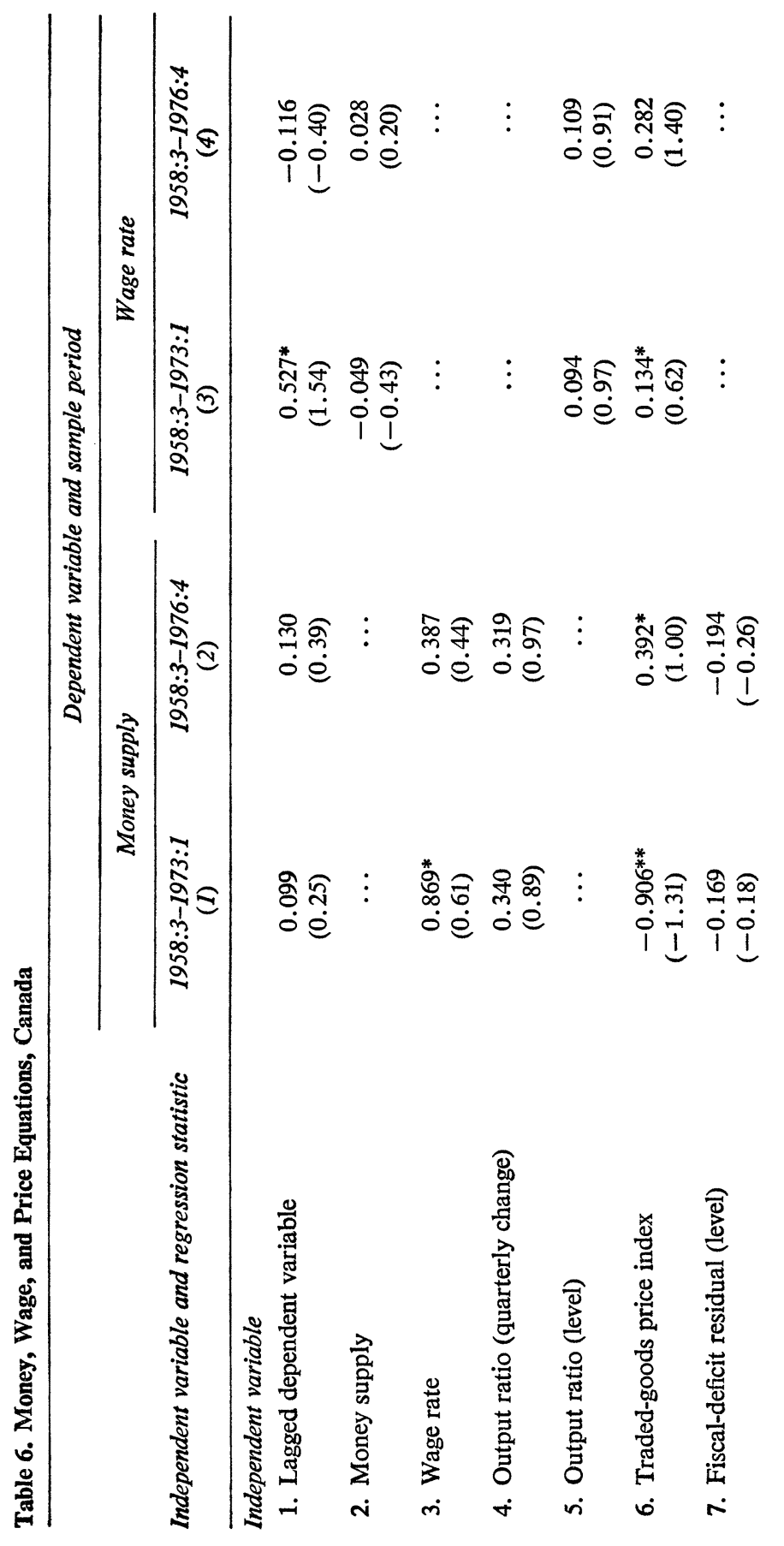




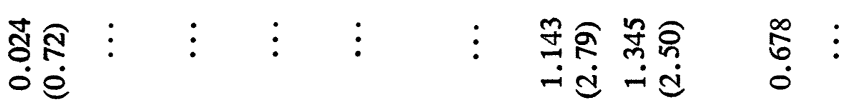

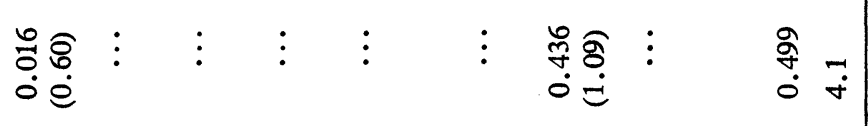

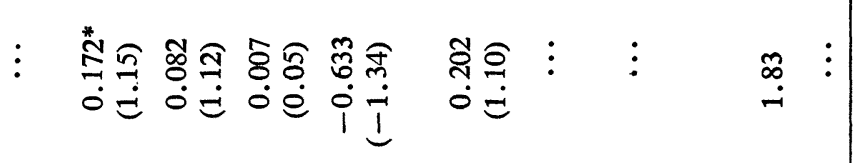

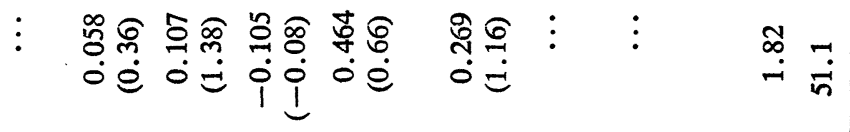

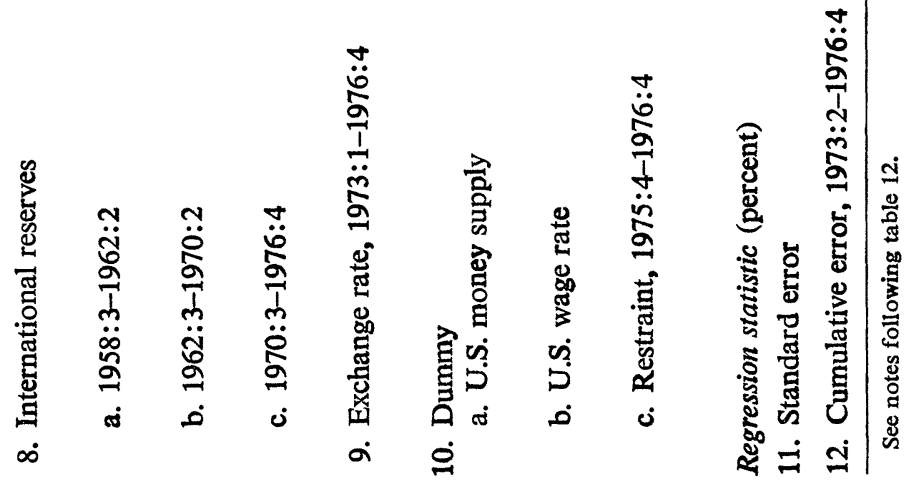




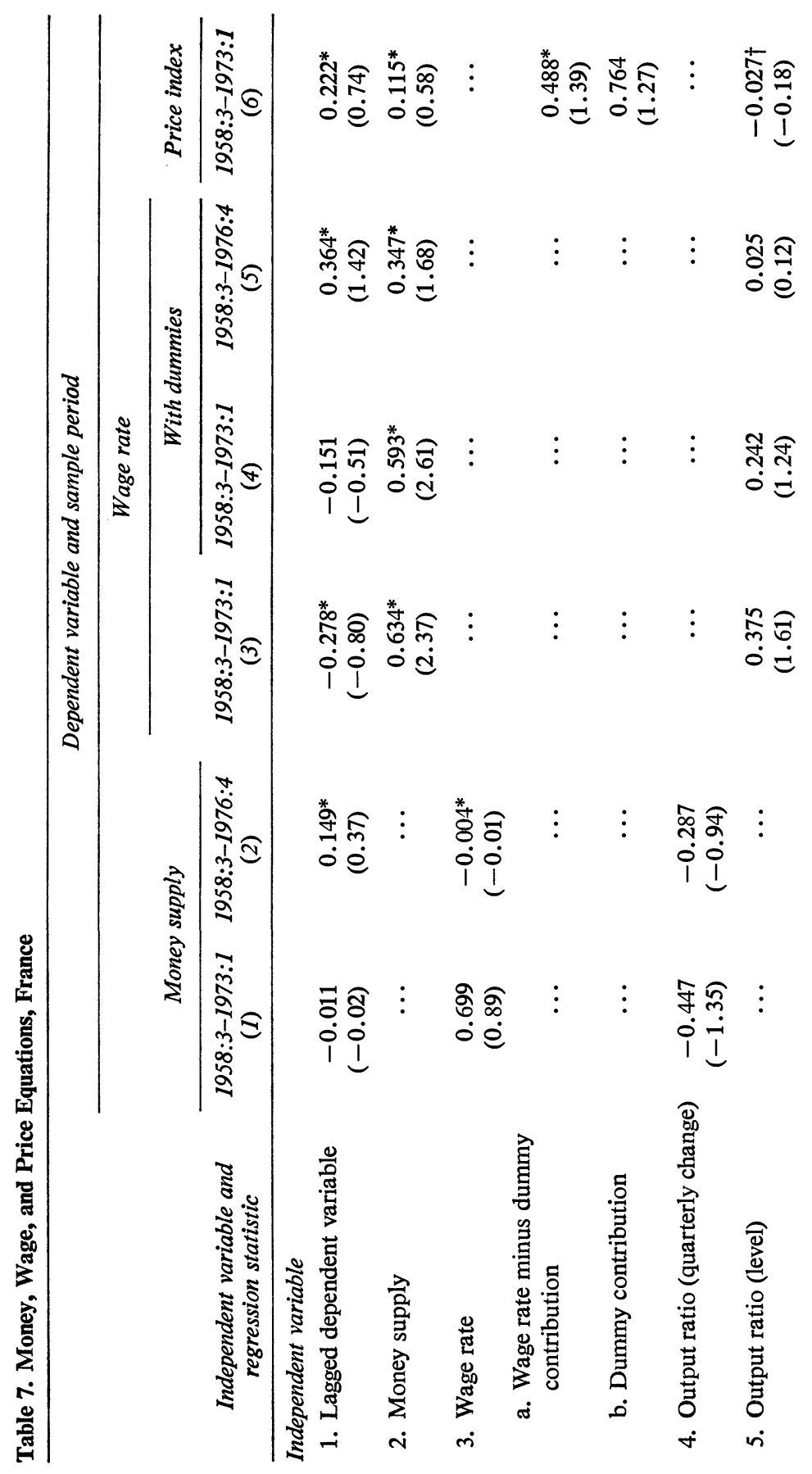




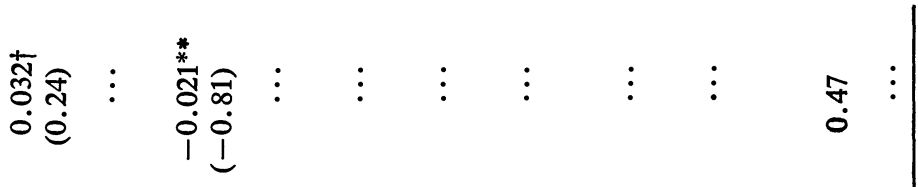

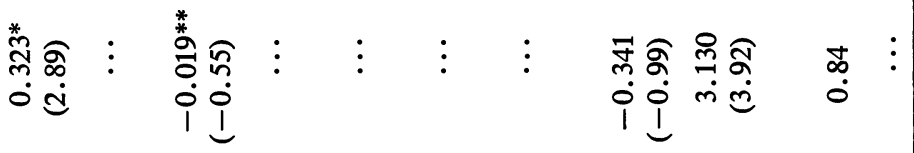

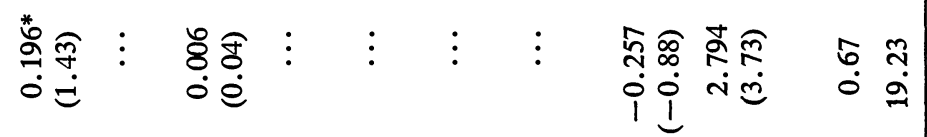

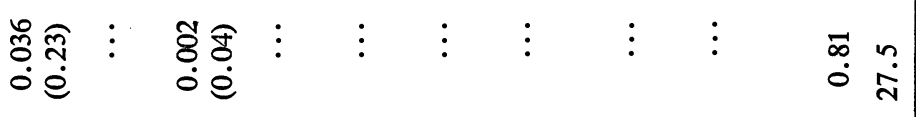

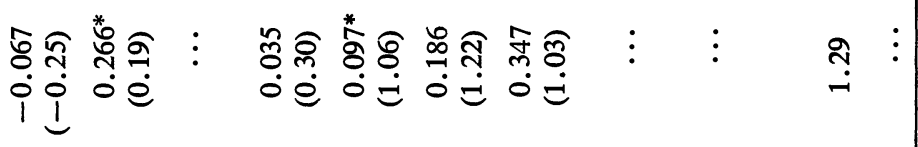

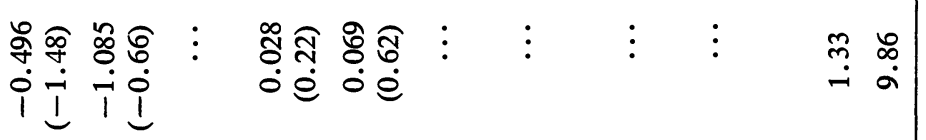
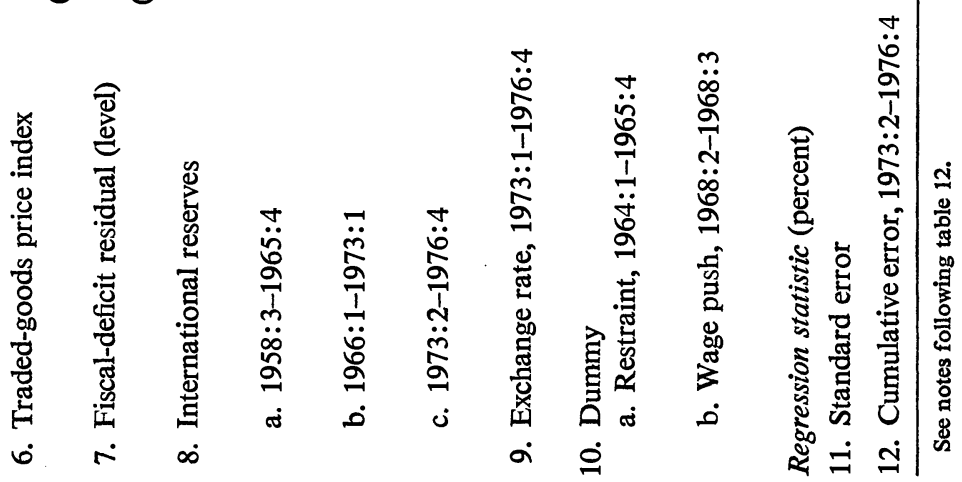


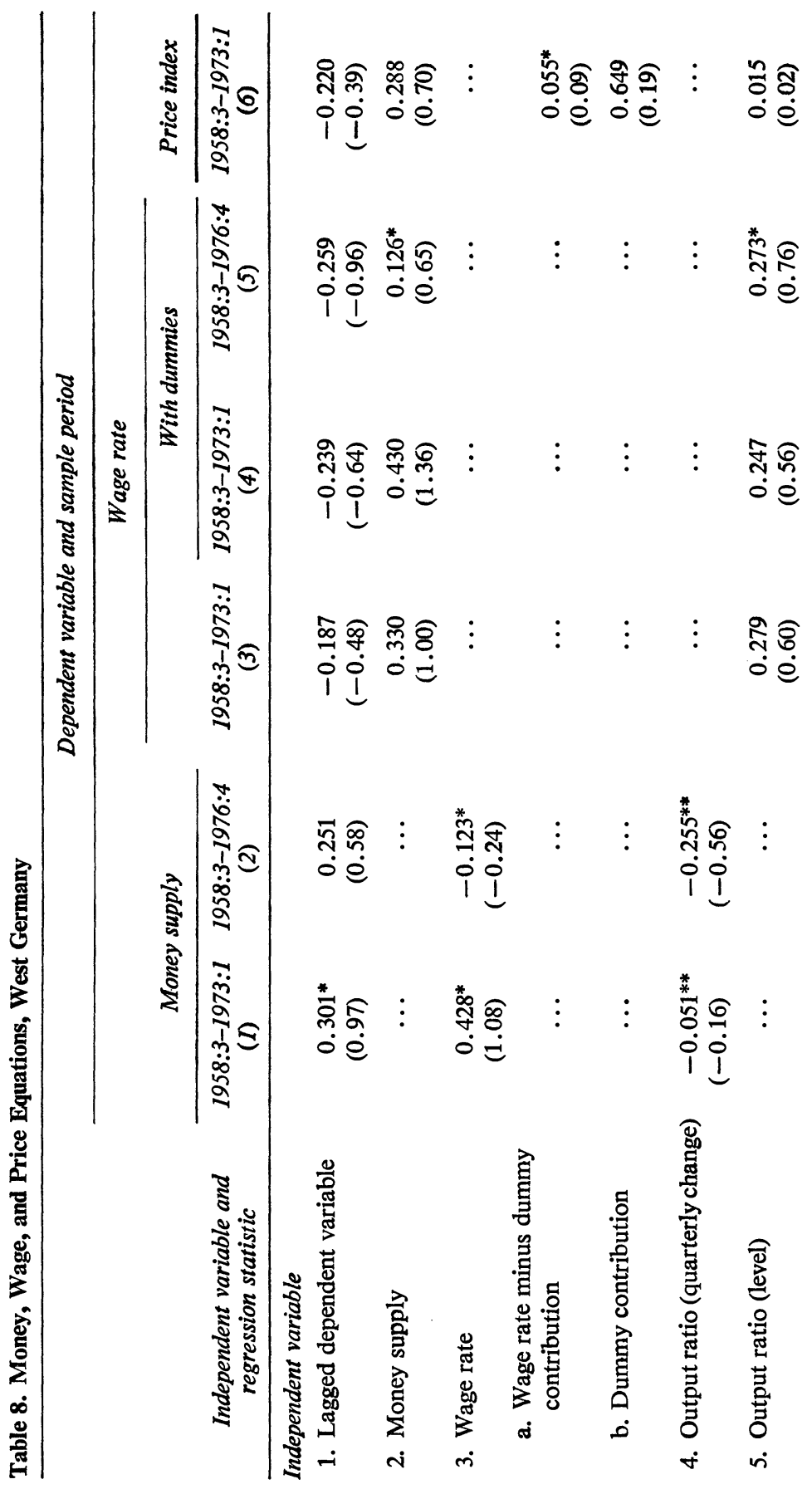




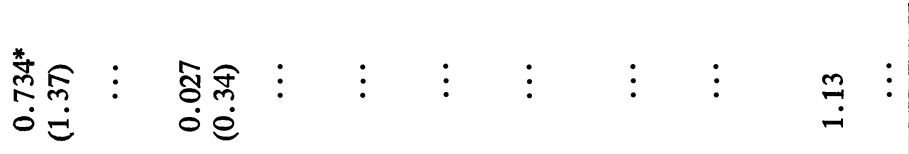

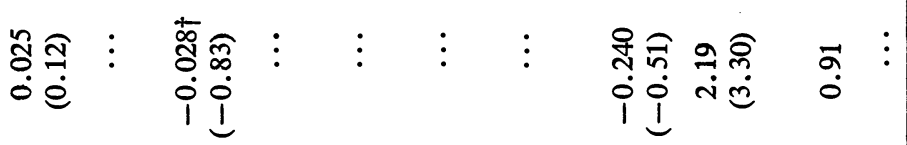

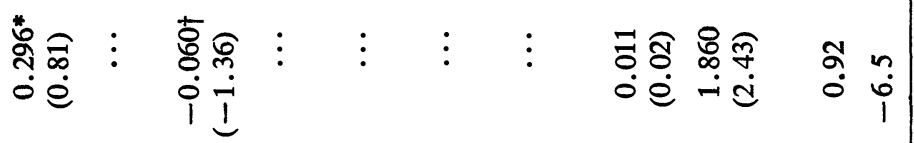

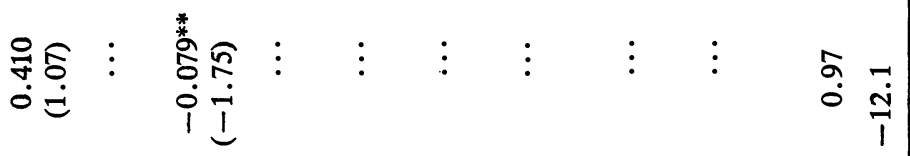

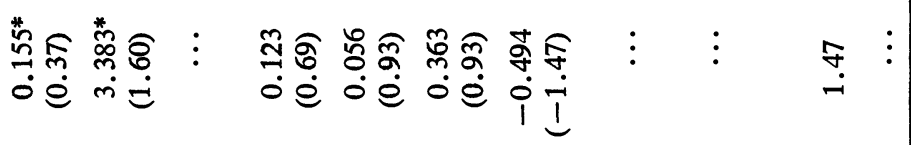

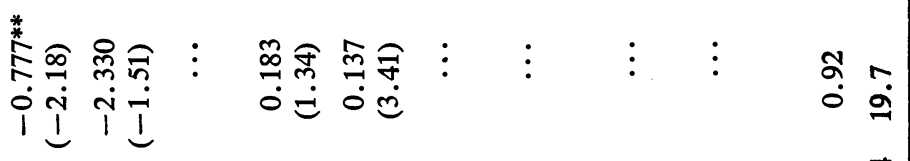

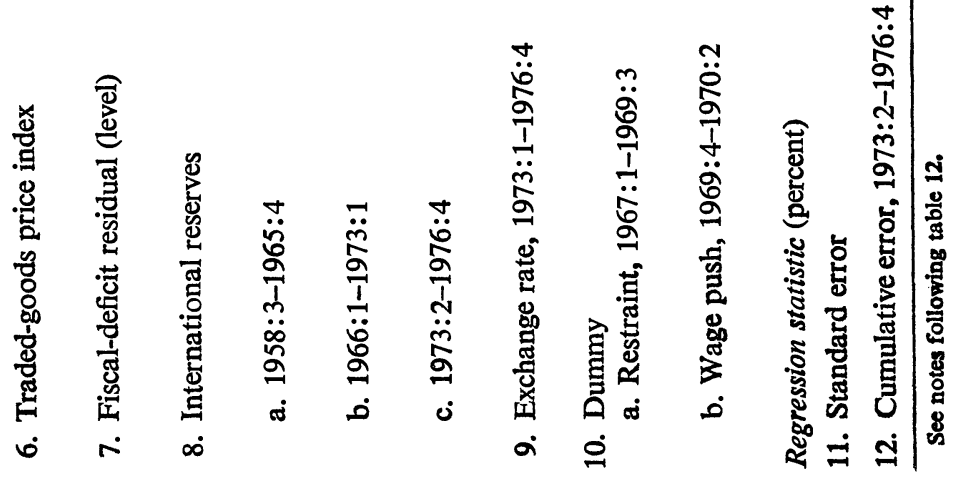




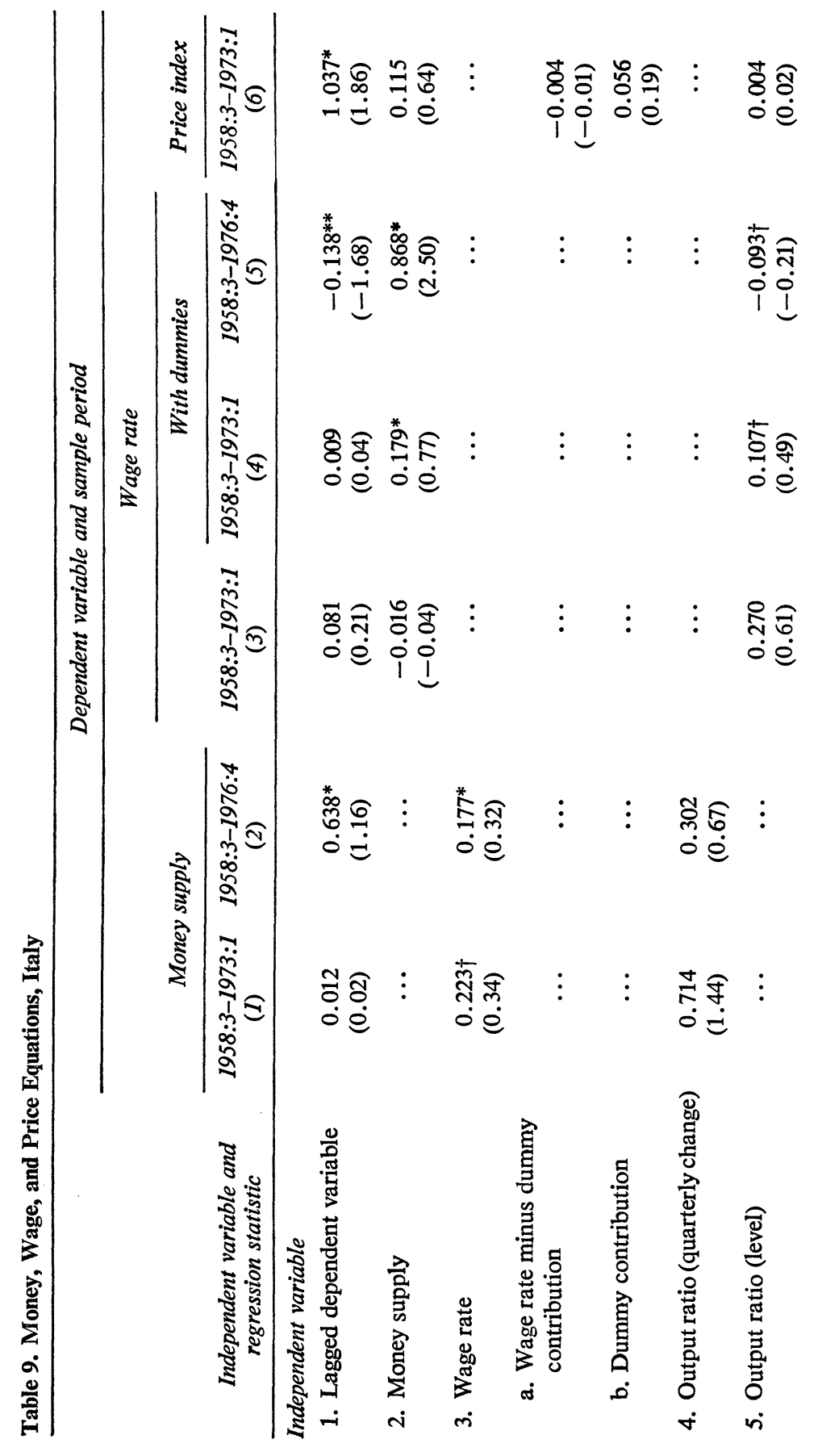




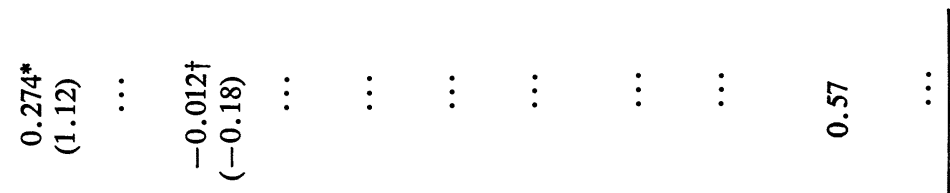

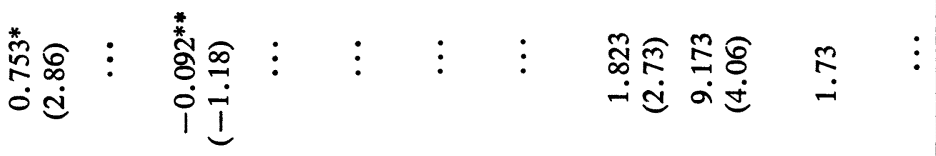

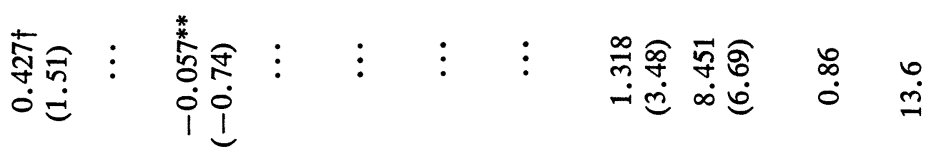

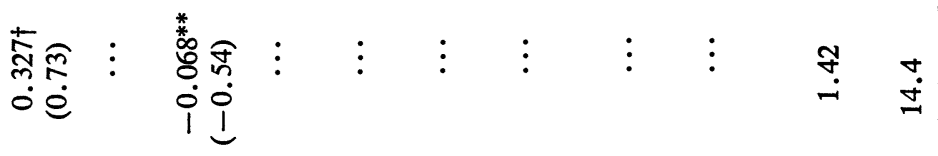

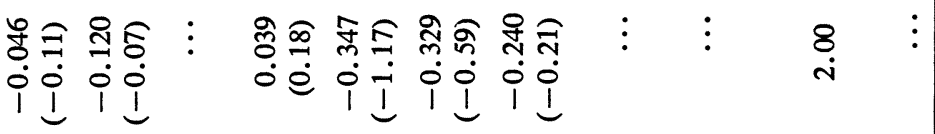

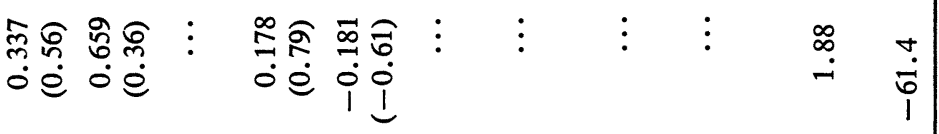

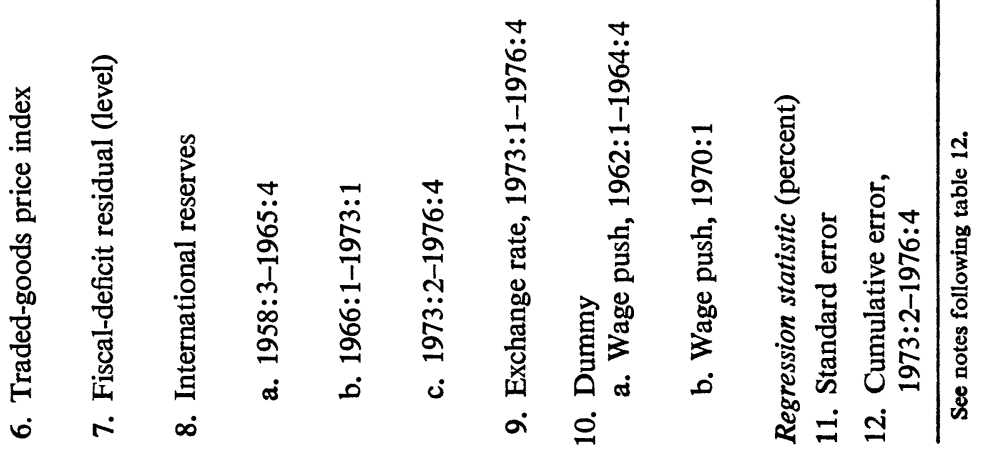




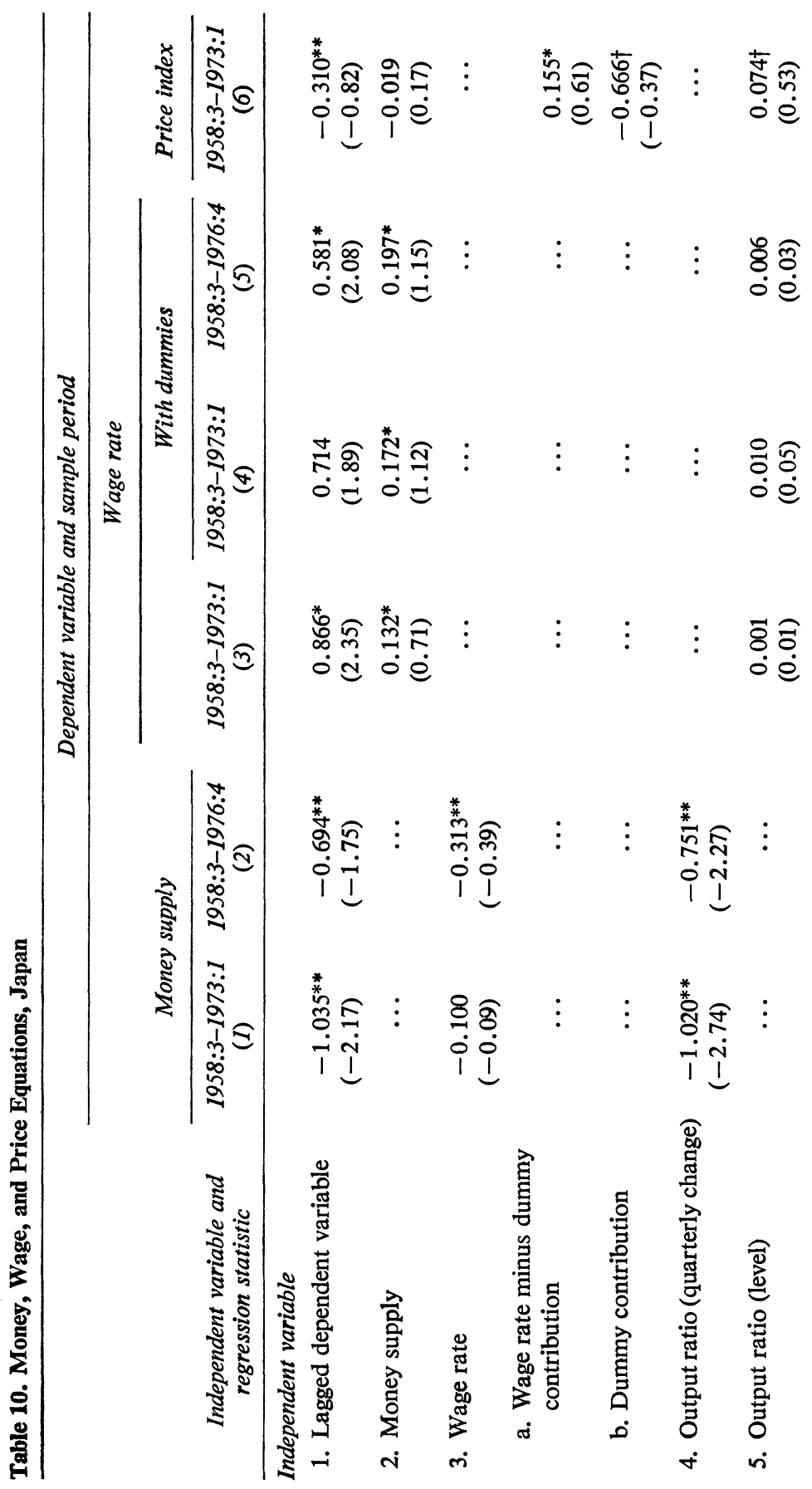




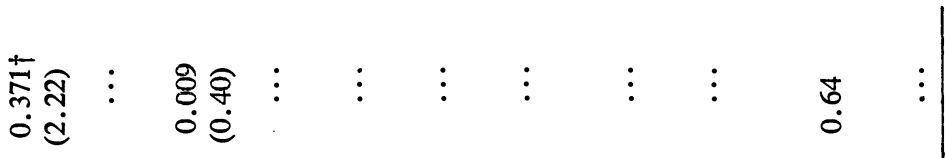

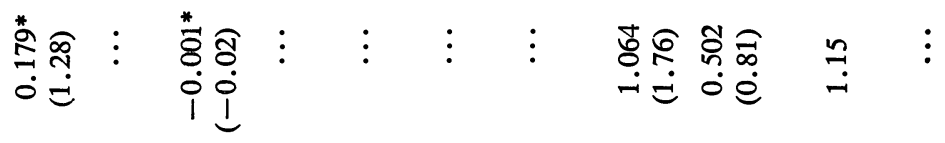

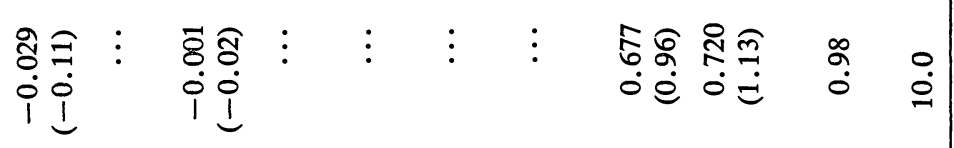

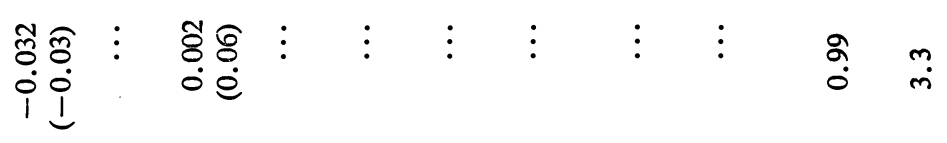

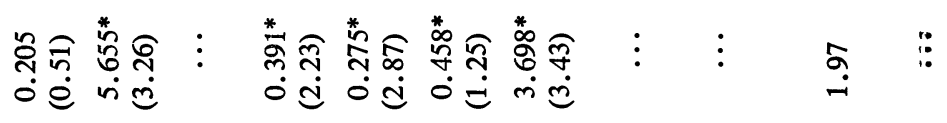

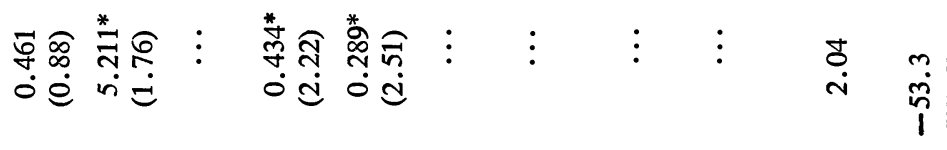

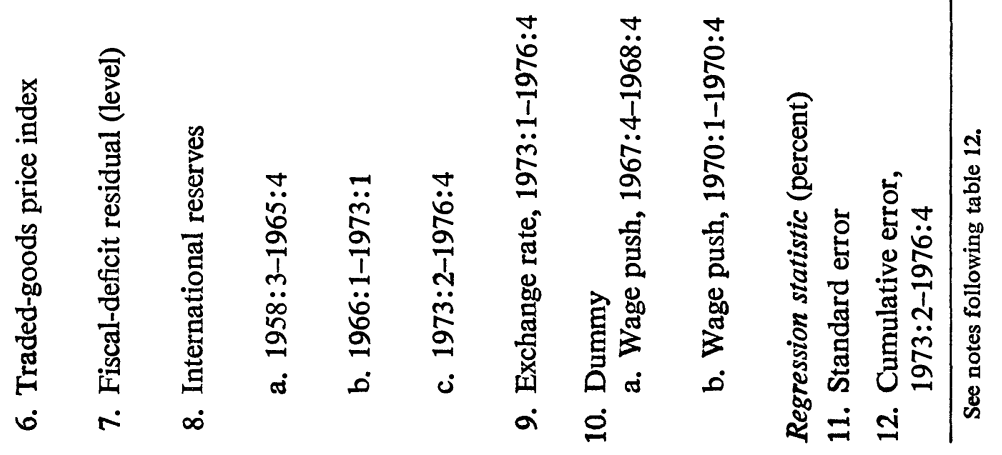




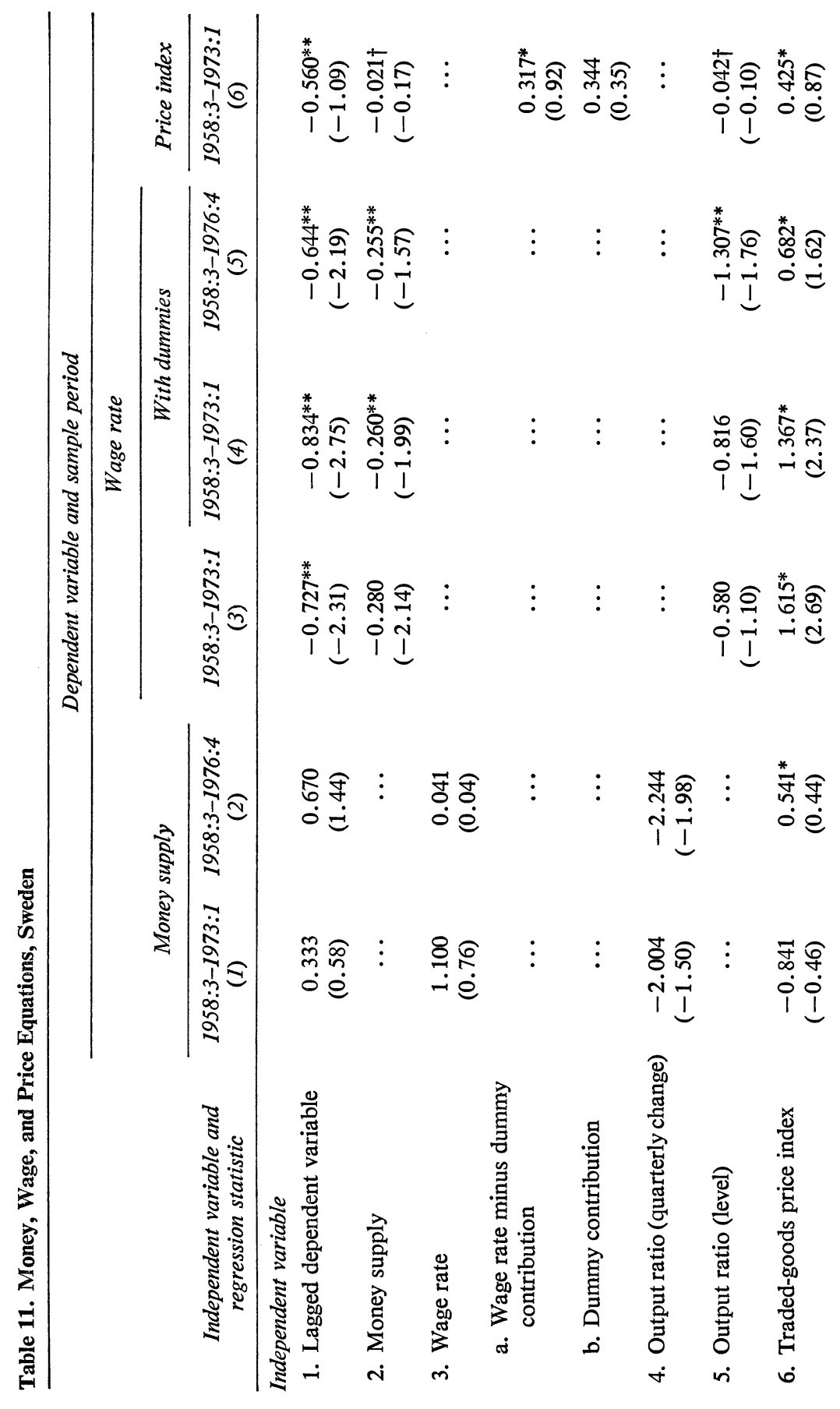




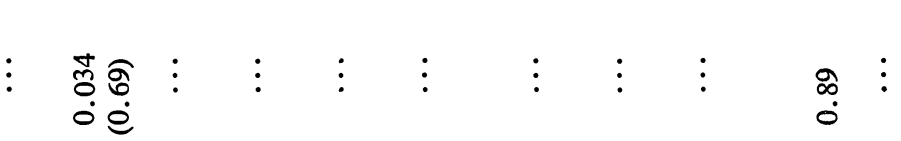

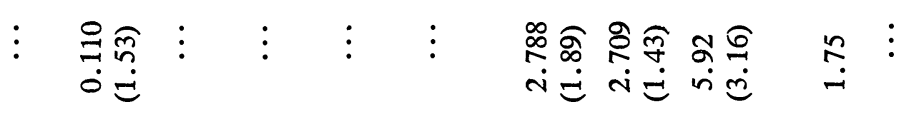

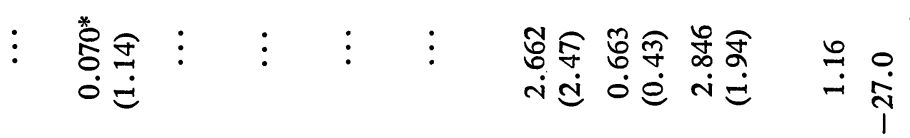

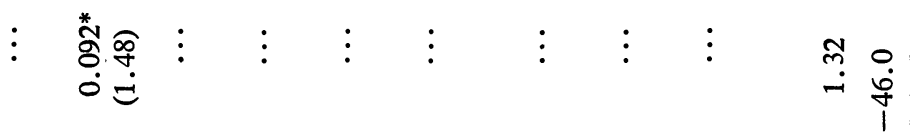

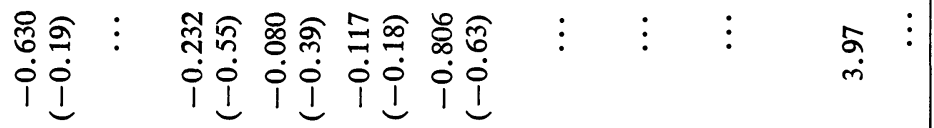

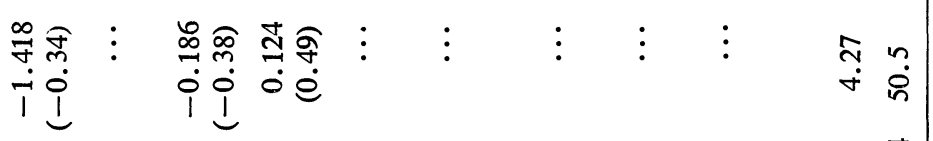

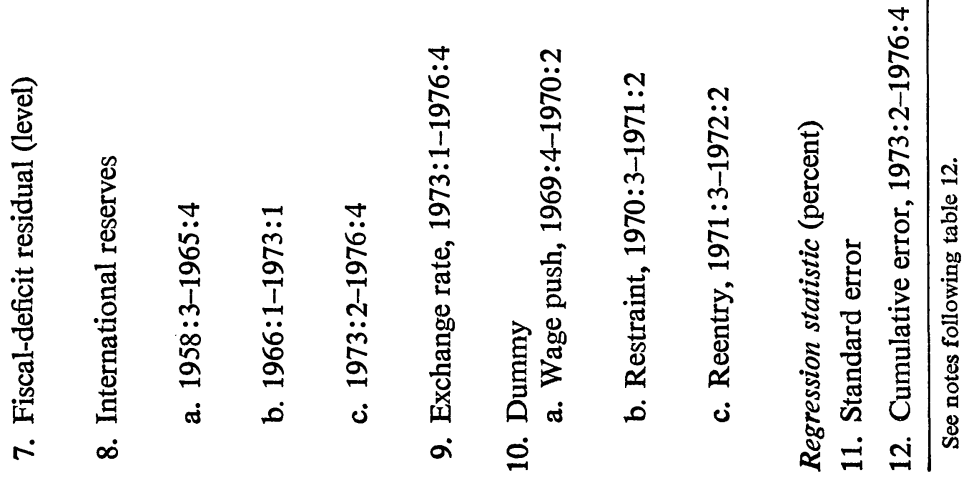




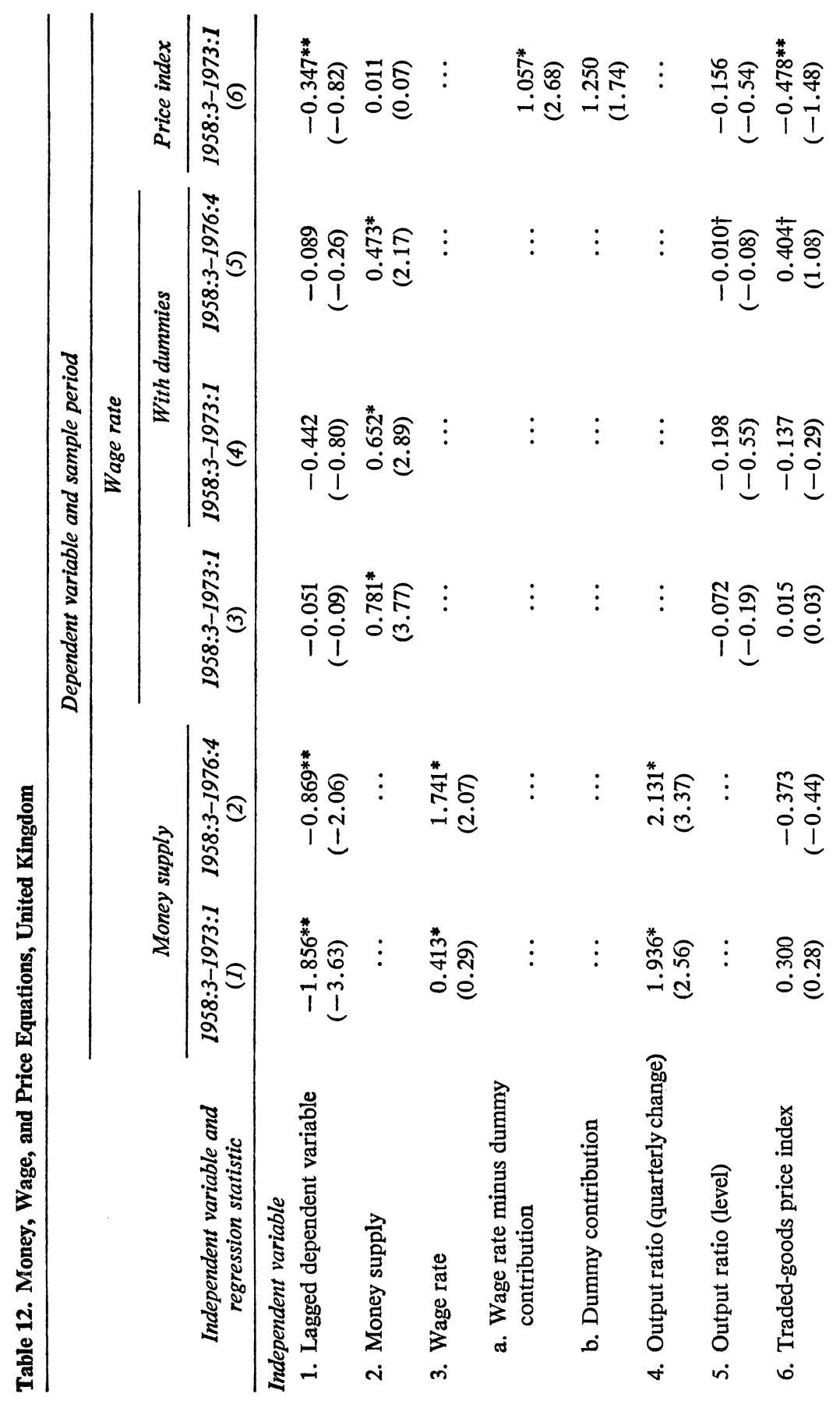




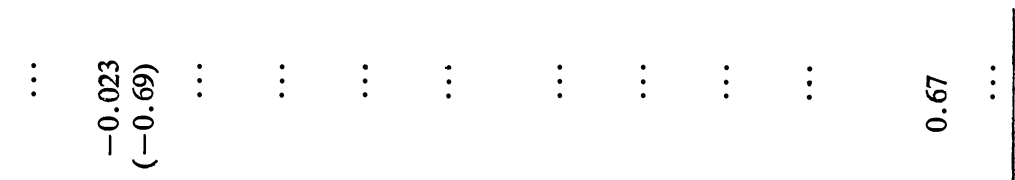

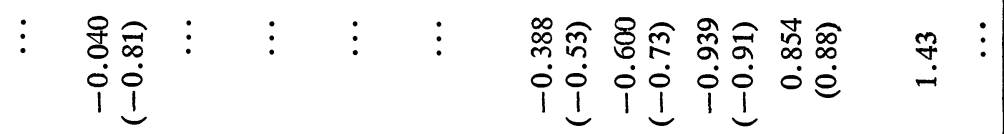

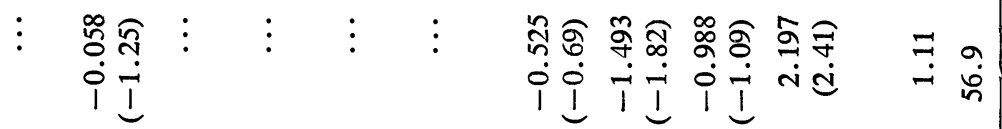

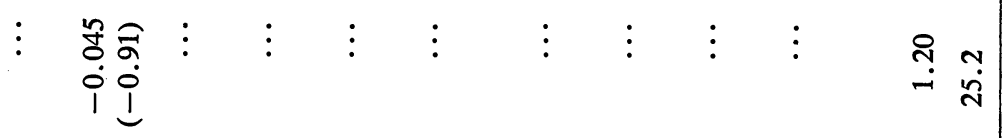

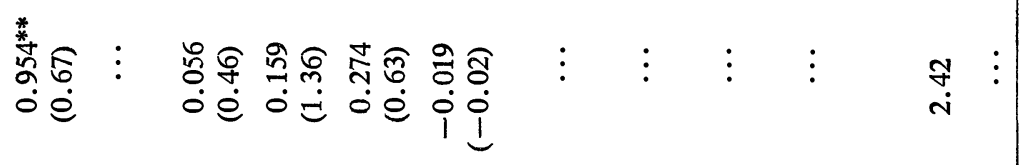

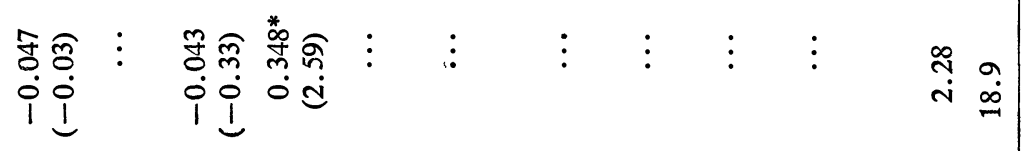

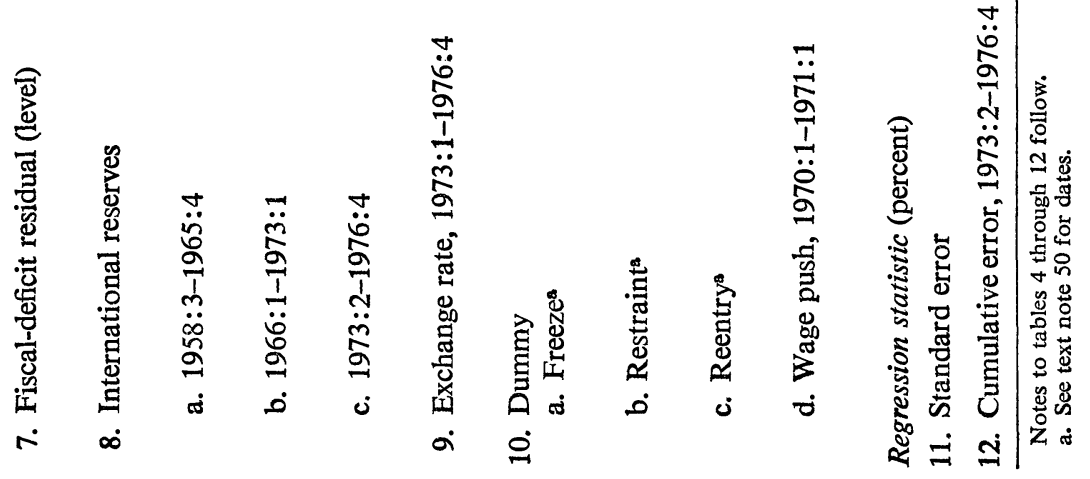




\section{Notes to Tables 4 through 12}

Unless otherwise indicated, all variables are one-quarter rates of change in percent. The numbers in parentheses are $t$ ratios.

All coefficients and $t$ ratios represent the sum of a series of freely estimated coefficients. The number of individual coefficients is as follows: All equations-lagged dependent variable, four coefficients. Money equation-wage variable, current and four lagged coefficients; other independent variables, current and three lagged coefficients. Wage and price equations-all independent variables, current and four lagged coefficients.

The money concept is $\mathrm{M}_{1}$ for all countries except Canada and France, for which it is $\mathrm{M}_{2}$.

In addition to the coefficients listed in the tables, each equation includes as additional independent variables a constant term and three seasonal dummy variables.

The money equations contain political dummy variables set equal to unity in the quarter of each national election and the three preceding quarters, with one political dummy coefficient per election.

In cases where the sum of coefficients is not statistically significant, one or more individual lagged coefficients nevertheless may be significant. The superscripts indicate significance at the 5 percent level (one-tailed test) of one or more positive individual coefficients $(*)$; one or more negative coefficients $(* *)$; and one or more coefficients of both signs $(\dagger)$.

Standard errors, cumulative extrapolation errors, and coefficients on dummy variables are listed as percentages.

Cumulative errors in line 12 do not include the effect of any dummies that are applicable only in the period after 1973:1—for example, the U.S. reentry dummy in table 4 , line $9 \mathrm{~d}$.

A detailed data appendix is available from the author on request. 


\section{Comments and Discussion}

Robert E. Hall: The two most interesting hypotheses investigated in Gordon's paper are, first, the proposition that monetary expansion and little else drives inflation; and second, the contrary proposition that wage inflation rises or falls of its own accord, independent of money or other determinants of demand. To keep my discussion simple, I will focus on wage rather than price inflation. The wage-push hypothesis is supported by any evidence that wages behave in a way that is not predictable from the behavior of money and other determinants of demand. The extreme wage-push hypothesis requires, moreover, that demand have no role in predicting wages. The believer in wage push is hoping for a wage equation with large unexplained residuals and low coefficients for money and the real output gap. Obviously, Gordon's research cannot fail to turn up some evidence in favor of wage push. Everyone grants the wage equation some residuals.

Just the opposite evidence would support the monetarist hypothesis. Wages should be highly predictable and money should have an important role in the prediction. The monetarist hopes that the wage equation will fit well and that demand will matter. It is noteworthy that, from the perspective of this paper, much of Gordon's past research has been devoted to establishing a monetarist proposition-namely, the success of the Phillips curve. Still, there is an evident bias in the procedure of this paper in favor of the wage-push hypothesis-every user of econometrics knows how easy it is to run unsuccessful regressions.

The interpretation of Gordon's results for wages presents some challenges. For the purposes of my discussion, equation 3 in the individualcountry regressions is the relevant one. There is wide variation among countries in the standard errors of the regression. The U.S. equation is by 
far the best, with a standard error of 0.18 (implying a typical forecast error of wages one quarter ahead of 0.18 percent). Worst are those for the United Kingdom (1.20), Sweden (1.32), and Italy (1.42). But much of the success of the U.S. wage equation arises from the lagged rates of wage inflation. This finding of persistent wage inflation is no surprise: every modern Phillips curve has some kind of "expectation" term of this kind. What is surprising is the unimportance of lagged wage inflation in many other countries. This is a kind of confirmation of the wagepush hypothesis: there are isolated large surprises in the inflation rate that make the serial correlation of wage changes low or even negative. In any case, the unpredictability of wage inflation outside the United States is confirmed by these results.

Money and other demand variables are not without influence in some countries, according to Gordon. The wage-push hypothesis is not universally true in its extreme form. Still, quite apart from the subsidiary question of why monetary growth has fluctuated, these results make clear that nowhere is there a close correlation between monetary expansion and wage inflation that operates with only a brief lag. My own view that money has a quick and strong effect on real output but that its effect on wages and prices takes much longer is not changed by these results.

My principal misgivings about Gordon's results relate to their sensitivity to measurement error. Nothing in the procedure can distinguish between a wage push and a blunder by the national statistical agency. Errors in measuring money and other right-hand variables would also explain their weakness in Gordon's regressions. It seems unlikely that a tight relationship between money and wages lurks in his data, concealed by measurement errors, but some part of the findings that are favorable to wage push are probably artifacts of these errors.

A basic point of the paper is that the wage equation has large residuals in every country but the United States. Gordon chooses to express this finding by putting in dummy variables for major episodes of unexplained wage inflation and then noting the large coefficients of these variables. Since fishing around for good dummies is a notorious practice of certain schools of econometrics, it seems to me that the use of dummies, to which I have no serious objections here, can only detract from the paper. It would be much better just to show the reader the residuals. Certainly the reader learns nothing from the coefficients of other variables in regres- 
sions in which dummies make up for the conspicuous failure of the variables to explain major episodes of wage inflation.

Michael Parkin: International monetarism is a body of analysis that seeks to explain world inflation under a regime of fixed exchange rates. Wage push is a view of the causes of inflation at the national level. In view of this fundamental difference in the phenomena that they seek to explain, it is difficult to discriminate between these two views of the world. Gordon attempts to do so by examining inflation at both the world aggregate and national levels. At the level of world aggregates, international monetarism looks convincing. However, at the national level many puzzles remain, including in several cases a complete lack of significance of monetary factors in the inflation process.

A fundamental specification problem could be at the source of this. While the international monetarist views world inflation as determined by a standard macromonetary process, he emphasizes that at the national level, price movements contain important relative-price adjustments, the national inflation rate being equal to the world inflation rate adjusted for that nation's relative-price movements. The source of national relativeprice movements emphasized by international monetarists is the difference between (1) an individual country's differential growth rate of productivity in its traded- and nontraded-goods sectors, and (2) the average differential in the rest of the world. ${ }^{1}$ A country whose rate of productivity growth in its traded-goods sector exceeds that in its nontraded-goods sector by an amount greater than that which on average is occurring in the rest of the world will, under fixed exchange rates, experience a rate of increase in its domestic price index higher than the world average. This consideration determines the trend deviation of a national "inflation" rate from world inflation. In addition, there is room for cyclical deviations of the national "inflation" rate from world inflation, again arising from changes in international relative prices as between traded and nontraded goods. A country that is generating an excessive rate of expansion of domestic credit will at the same time be experiencing a current-account deficit. This will be associated with a rise in the price of its nontraded goods relative to the world price of traded goods since, as the

1. See Michael Parkin, "World Inflation, International Relative Prices and Monetary Equilibrium Under Fixed Exchange Rates," in Robert Z. Aliber, ed., The Political Economy of Monetary Reform (London: Macmillan, 1977), pp. 220-42. 
country attempts to raise its expenditure level relative to its income level, it will substitute toward domestic nontraded goods, satisfying its excess demand for traded goods from foreign sources. This substitution in the production process will be associated with a more rapidly rising price of nontraded goods. Thus the rate of inflation of domestic prices will deviate from the world inflation rate both for trend reasons (due to underlying differentials in productivity growth) and for reasons due to cycles in the rates of domestic credit expansion and the national balance of payments. ${ }^{2}$

The above remarks concerning the national price index also hold for the wage index and therefore suggest that Gordon's formulation of the determinants of national wage changes do not accord with the predictions of the international-monetarist school. He focuses on what might be called closed-economy monetarism with the ad hoc addition of an international relative price-namely, the price of the country's actual traded goods (a simple average of export and import prices for each country). His wage equation for the international-monetarist view has domestic money, domestic output, traded-goods prices, and international reserves as explanatory variables. For the international monetarist, the wage equation for an individual country (in reduced form) would contain the rate of growth of the world money supply, the difference between the productivity growth rates in the tradables and nontradables sectors in the country in question relative to that difference for the rest of the world. No other variables would appear in an international monetarist's reduced-form equation for domestic wage (or price) inflation.

Gordon presents a full and fair account of the wage-push view put in perhaps its best light. However, his empirical formulation of the approach seems to me to miss the central proposition that that school has sought to advance. It also raises the oft-asked question: What is the explanatory variable (or set of explanatory variables) that the wage-push school views as generating inflation? First, recall that the central fact that the wagepush school sought to explain was the widespread tendency for the shortrun relationship between inflation and unemployment to drift upward following 1966. This, more than anything else, was what gave rise to dissatisfaction with the previously conventionally accepted Phillips-curve

2. Michael Parkin, "Inflation, the Balance of Payments, Domestic Credit Expansion and Exchange Rate Adjustments," in Robert Z. Aliber, ed., National Monetary Policies and the International Financial System (University of Chicago Press, 1974), pp. 49-63. 
hypothesis and to the widespread popularity of the invocation of wagepush "sociological" sources of the "new inflation." Gordon's formulation, at least in the way it is implemented, is incapable of addressing this feature of the wage-push school. His procedure of "peeking" at the data and then dummying out the large residuals amounts in effect to restricting the wagepush hypothesis to one about "blips" in the evolution of wages. Many previous wage studies have suggested that, apart from some sizable random movements, no mystery attends the overall movement of money wages, given the development of other standard macroeconomic variables that are widely alleged to affect wages. However, the wage-push proponent could still argue that his position has not really been tested. $\mathrm{He}$ would see the broad trend of monetary policy, rather than its quarter-byquarter variation, as the factor responding to whatever underlying social pressures are generating inflation. In other words, the wage-push view (as I understand it) is a theory of broad trends in inflation rather than of minute movements from quarter to quarter or year to year. That broader formulation is not addressed in Gordon's paper, even though that paper goes much further than any previous study in trying to do justice to the wage-push views. The wage-push advocate would probably argue that the same factors that cause wages to rise also cause monetary growth. In other words, it is not that wages "cause" money but that social forces (somewhat ill-defined) cause both rising wages and accommodating money. Causality tests therefore would require the explicit identification of the exogenous social variables.

Of the battery of coefficients estimated and reported by Gordon, only two emerge as crucial for discriminating between the wage-push and international-monetarist hypotheses. The first is the coefficient on wages in the money equation. This needs to be significantly positive for the wage-push view to be correct, implying that money accommodates previous wage movements. Zero coefficients on wages in the money equation would indicate that wages do not "cause" money (that is, are not accommodated). On this test international monetarism scores eight and wage-push zero. The second important coefficient, at least in the Gordon framework, is that of the wage-push dummy variables in the wage equations. The international-monetarist position requires that these be zero while the wagepush view requires them to be significantly positive. On this competition, wage push wins five to three. However, the rules of the game- " "peeking" at the data and then simply using a dummy variable to pick up the effects 
of any previously observed large movements in wages-virtually guarantee a victory for the wage-push view. Robert Hall said enough about the difficulties and problems with using dummy variables in this way. As conceived by Gordon, the international-monetarist hypothesis requires that money appear significantly positive in the wage equations. This result occurs only in the case of the United States, France, and the United Kingdom with any strength, and in the case of West Germany with less strength. For Sweden there is a significantly perverse effect and for Canada and Italy no measurable effect at all. It may appear that this indicates a defeat for the international-monetarist position. However, as indicated above in the remarks concerning the appropriate specification of that view, there is no strongly predicted relationship between national money supply and national wages unless relative-wage changes arising from differentials in international productivity growth are also allowed for. Furthermore, collinearity may be present, arising from the inclusion of the output ratio as well as money in these wage equations. In view of the misspecification of the international-monetarist hypothesis concerning movements of national wages and national prices, no strong inference about the appropriateness of that set of hypotheses can be drawn from the estimation of the particular wage equations included in this paper.

Despite its weaknesses, this massive study by Gordon does seem to contain some elements of policy conclusion. They are that, insofar as one can draw inferences from this body of work, monetary policy has to bear the brunt of the fight on inflation, and, while direct controls can have some marginal impact, they do not appear to be capable of moving the broad trend of inflation away from where the monetary aggregates are taking it. Much more important, however, than the policy conclusions are those concerning an agenda for research. Gordon does not spell out such an agenda, but in many ways one is implicit in what he has done. The first question that arises concerns the identification of the exogenous causes of wage push. Not until such variables have been specified can proper causality tests be undertaken that are capable of rejecting (or confirming) the wage-push view. Second, when the specification is changed so as to characterize international monetarism and the wage-push view more precisely, how robust are the empirical findings? This is the minimum research task that must be undertaken before the questions raised here are finally laid to rest. 
Robert J. Gordon: Let me respond to Parkin's comment by defending the paper's inclusion of domesicic money in the wage equation. Parkin's own account of IM associates a domestic credit expansion with an increase in prices of domestic nontraded goods, which must be accompanied by (1) an increase in domestic wages, and (2) an increase in the domestic money supply (unless reserve flows totally offset the domestic credit expansion, an extreme position rejected by previous empirical work). The basic Dornbusch IM paper (see text note 10 above) is centered on the connection between domestic wages and money.

Parkin's remarks on wage push center on the distinction between episodic "blips" and "broad trends." A basic point of the paper is that individual episodes of wage acceleration cannot be a source of a "broad trend" toward more inflation unless (1) the higher wages raise prices rather than squeezing profits, and (2) the money supply accommodates the wage increases. Parkin asks that "social forces" rather than wages be linked to monetary growth, but it is hard to see how these forces could be a source of inflation without raising wages as well as money, and this relationship should be revealed in positive coefficients on current or past wages in the money equation or both.

Robert Hall's distaste for dummy variables is understandable, but there is no available alternative to test for the presence of autonomous wage movements. The paper introduced dummies in the wage equation not to soak up every extreme residual, but only for use in episodes previously identified by others as cases of wage explosion or acceleration. The "peeking" involved only determining the exact duration of each episode, not the choice of the episodes themselves. Omission of the dummy variables would have biased the coefficients on the other independent variables in the wage equation, as is evident in a comparison of columns 3 and 4 of tables 4 through 12 . In particular, the impact of money on wages is appreciably stronger when the dummy variables are included.

\section{General Discussion}

Several participants felt that Gordon had not provided an adequate test of the wage-push hypothesis. Thomas Juster cautioned that the difficulty of testing for phenomena such as "the effect of improved communi- 
cations on wage aspirations" did not mean that they could be ignored in serious explanations of wage behavior. Charles Holt noted that some success has been obtained by Dicks-Mireaux in using proxies for union aggressiveness in wage equations, and suggested that Gordon might have modeled such processes more effectively. Michael Wachter argued that since some versions of wage push implied that relative-wage changes in particular sectors trigger inflation, disaggregated wage equations would be needed to test the wage-push hypothesis. Gardner Ackley pointed out that in testing for wage push, Gordon had ignored the role of the wage-determination process in regular secular movements of wages and prices. A persistent inflationary push arising from wage-setting institutions would not be identified by Gordon's tests.

Several comments were made about Gordon's results. John Shoven observed that the equations were largely unsuccessful and confirmed no hypothesis, except possibly an extreme version of wage push such as Hall had in mind. Money could not be said to cause wage or price movements and wages could not be said to cause changes in money. Edmund Phelps was dissatisfied because Gordon's equations implied that a 1 percent change in both the money supply and traded-goods prices would not, asymptotically, imply anything like a 1 percent change in wages. Together with Martin Baily, Phelps also objected that Gordon had overlooked the numerous changes in exchange rates that had been made under the fixedexchange-rate regime as well as the intervention that has gone on under the system of "flexible" rates. Baily cautioned that the exogeneity tests Gordon relied on applied only asymptotically for large samples, and were not reliable for small samples.

James Duesenberry and Ackley both found Gordon's modeling of policy decisions too simplistic. Duesenberry pointed out that monetary policy did not conform to a single pattern. At some times policymakers will accommodate demand shifts; at others they will pursue a countercyclical course. And even if they might initially have a restrictive reaction to an inflationary shock, over a longer horizon, if the inflation persisted, they might well accommodate the higher track in wages and prices. Duesenberry further reasoned that the trend in wages would help determine the trend in money, but that this connection might well be lost in equations such as Gordon's. Ackley stressed the complexity of policymakers' behavior. Policy might be wrong, and then changed as participants learned; reactions might be nonlinear, different for small than for large 
changes. The evidence suggested that policy is exogenous. Attempts to endogenize policy have not been fruitful and one did not learn as much from the statistical summaries represented by Gordon's equations as one would by simply examining policy episodes directly.

Pentti Kouri noted that the coefficient on the reserves variable in the money-supply equations contained a downward bias and might incorrectly indicate that the money supply was exogenous when in fact it was moved by reserves. There are, potentially, two distinct relations between reserves and the money supply, one positive and one negative. There would be a positive relationship to the extent that authorities did not fully sterilize a reserve inflow; there would be a negative relationship to the extent that expansion of the domestic money base led to some decline in foreign reserves. These effects should be isolated, with only the first one relevant to Gordon's inquiry.

Gordon was sympathetic with the reservations of Duesenberry and Ackley. Reactions of policymakers were complex, and coefficients in reaction functions might vary. If fixed coefficients in the money equation turned out to be insignificant in the paper, indicating exogeneity of money, this did not rule out the possibility that endogenous policy reactions might be identified by further research with nonlinear or variable coefficients. Nevertheless, several strong results emerged from the money equations, including the failure of Japan and Germany to sterilize reserve inflows and the sensitivity of Japan to both the balance of payments and the domestic business cycle.

Gordon disagreed with Shoven's remark that the results did not exhibit strong effects of money on wages. Although this was true in the aggregate, the significant, if small, coefficients on money in most of the country equations provided evidence that central banks may have more influence over wage determination than they realize. In particular, the strong feedback between money and wages in the extended equations for Italy and the United Kingdom shed light on a source of their problems in the 1974-76 interval. 